\title{
MUNICIPAL “DiRECTION, CONTROL AND MANAGEMENT” OF LOCAL WETLANDS AND ASSOCIATED RIPARIAN LANDS: SECTION 60 OF ALBERTA's MUNICIPAL GOVERNMENT ACT
}

\author{
JUDY STEWART ${ }^{*}$
}

Section 60 of the Municipal Government Act authorizes municipal "direction, control and management" of Alberta's rivers, streams, watercourses, lakes, and other natural bodies of water within the municipality. There is little legal interpretation of s. 60, and even less municipal water body management planning, or water management plan implementation at the local level. In this article the author reviews s. 60, including the legislative history of the phrase "direction, control and management." Section 60 is interpreted in light of constitutional doctrines and Alberta Water Act provisions for water management planning. "Watershed management planning" is underway in Alberta pursuant to Water For Life: Alberta’s Strategy for Sustainability and municipalities have a role to play.
L'article 60 de la Municipal Government Act autorise la «direction, le contrôle et la gestion» de rivières, ruisseaux, cours d'eau, lacs et autres plans d'eau naturels de l'Alberta au sein de la municipalité. Il y a peu d'interprétation juridique de l'article 60 et encore moins de planification de la gestion de l'eau par la municipalité ou de mise en œuvre de plan de gestion d'eau au niveau local. L'auteure de l'article examine l'article 60, incluant l'historique législatif de l'expression anglaise «direction, control and management» ( la direction, le contrôle et la gestion). L'article 60 est interprété à la lumière de doctrines constitutionnelles et des dispositions de la loi sur le régime des eaux de l'Alberta en ce qui concerne la planification de la gestion de l'eau. Le «plan d'aménagement des bassins hydrographiques» est en cours en Alberta conformément à Water For Life: Alberta's Strategy for Sustainability et les municipalités ont un rôle à jouer.

\section{TABLE OF CONTENTS}

I. INTRODUCTION . . . . . . . . . . . . . . . . . . . . . . . . . . 74

II. THE IMPORTANCE OF WETLANDS AND RIPARIAN LANDS $\ldots \ldots \ldots \ldots \ldots .76$

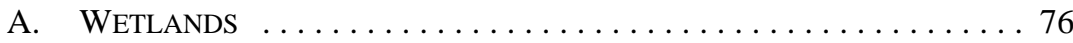

B. RIPARIAN LANDS $\ldots \ldots \ldots \ldots \ldots \ldots \ldots \ldots \ldots \ldots$

C. IMPORTANCE OF WETLANDS AND RIPARIAN LANDS $\ldots \ldots \ldots \ldots \ldots 78$

D. WETLAND AND RIPARIAN LAND OWNERSHIP ISSUES . . . . . . . . . . 79

E. The EXTENT OF Riparian LANDS IS Not AlWAys OBVIOUS . . . . . 80

III. OVERVIEW OF SECTION 60 OF THE MUNICIPAL GOVERNMENT ACT . . . . . 80

A. Section 60 is “SubJect to Any Other EnACtMENT" . . . . . . . . 80

B. INCONSISTENCY AND OPERATIONAL CONFLICT

BETWEEN BYLAWS AND ENACTMENTS $\ldots \ldots \ldots \ldots \ldots \ldots \ldots$

C. FEDERAL AND PROVINCIAL LAWS AND

Policies THAT MAY APPLy $\ldots \ldots \ldots \ldots \ldots \ldots \ldots \ldots \ldots$

D. IMPORTING THE DEFINITION OF

"WATER BODY” FROM THE WATER ACT . . . . . . . . . . 113

E. What ARE THE Limitations ON SECtion 60? . . . . . . . . . . 114

IV. INTERPRETING “Direction, CONTROL AND MANAGEMENT” . . . . . . . 114

A. BACKGROUnd . . . . . . . . . . . . . . . . . . . . . . 114

The author practices law in Cochrane, Alberta and recently obtained a Master of Laws degree from the University of Calgary based on a thesis entitled "Municipal Tools to Protect Wetlands and Riparian Lands in Alberta's White Zone.” This article is a revised chapter from the thesis. 


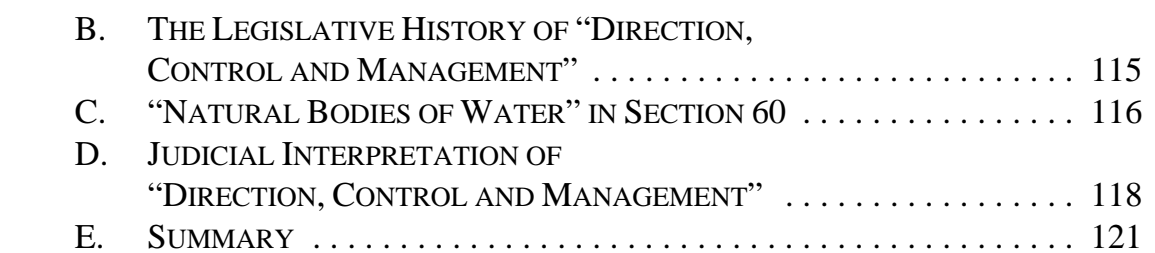

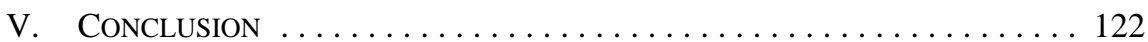

\section{INTRODUCTION}

Most Albertans live, work, and play in municipalities and their daily activities affect the natural environment. The landscape in the settled areas of Alberta, also known as the "White Zone," ${ }^{1}$ is undulating and pitted with wetlands and associated riparian lands. ${ }^{2}$ However, Alberta's natural landscape is rapidly changing due to growth in population, urbanization, and industrial and commercial activity. ${ }^{3}$

Almost 70 percent of Alberta's pre-settlement wetland inventory has been eliminated to accommodate human activities on the land. By 2004, 90 percent of the City of Calgary's presettlement wetland inventory was gone. ${ }^{4}$ Wetlands that have survived human settlement in both urban and rural municipalities are impacted to different degrees by subdivision, development, and agricultural practices. Alberta's inventory of wetlands is one of the "Genuine Progress Indicators" in Alberta, and a recent report from the Pembina Institute suggests that the number of wetlands in Alberta continues to decrease as human population

1 "White Zone" is a term used in Alberta to differentiate between settled areas containing mostly private lands and the "Green Zone," which typically consists of public lands. There are pockets of federal lands in both zones: see Alberta Forestry, Lands and Wildlife, "Figure 1: The Settled and Non-settled Areas of Alberta" in Alberta Water Resources Commission, Wetland Management Plan in the Settled Area of Alberta: An Interim Policy (Edmonton: Government of Alberta, 1993) at 2 [Interim Wetland Policy]. See also Government of Alberta, Riparian Land Conservation \& Management Project: Phase I Final Report (Edmonton: Alberta Environment, 2007) [Riparian Land Report], which summarizes conclusions and recommendations emerging from the Riparian Land Conservation and Management Project Committee, a multi-stakeholder discussion group on riparian land conservation and management in the White Zone around Calgary.

2 See Riparian Land Report, ibid. at 3 [footnotes omitted] for a suggested definition of riparian lands: "Riparian land is any land that adjoins or directly influences a water body and includes floodplains and land that directly influences alluvial aquifers." The Report notes that "[a] water body is any location where water flows or is present, whether or not the flow or the presence of water is continuous, intermittent or occurs only during a flood, and includes but is not limited to wetlands and aquifers (generally excludes irrigation works).” It then states that “[f]or the purpose of this definition, floodplain is synonymous with flood risk area. The flood risk area is the area that would be affected by a 100-year flood. This event has a one percent chance of being equalled or exceeded in any year" (at 3, n. 2). Finally, it states that "[f]or the purpose of this definition, alluvial aquifers are defined as groundwater under the direct influence of surface water (GUDI)" (at 3, n. 3).

3 "Economic Results,” online: Alberta, Canada <http://www.albertacanada.com/economy/739.html> ("Over the past five years, Alberta had the highest average rate of economic growth in Canada at 3.8\% per year”). See also “Canada's Population Estimates," online: Statistics Canada <http://www.statcan.gc.ca/daily-quotidien/090929/dq090929b-eng.htm> ("Alberta was the province with the fastest demographic growth rate from April to June 2009, at 0.59\%”).

$4 \quad$ Sara Wilson, Mary Griffiths \& Mark Anielski, The Alberta GPI Accounts: Wetlands and Peatlands, Report \#23 (Drayton Valley: Pembina Institute, 2001). See also Arlene Kwasniak, “Alberta Crown Ownership of Slough/Marsh Wetlands” (2007) 18 J. Envtl. L. \& Prac. 57 at 59 [Kwasniak, “Alberta Crown Ownership”]; City of Calgary, Calgary Wetland Conservation Plan (Calgary: Calgary Parks, 2004) at 6. 
and economic development based on natural resource extraction and related industry increases throughout Alberta. ${ }^{5}$

As wetlands disappear, so do the adjacent riparian lands. A 2007 Alberta Environment (AENV) report entitled Riparian Land Conservation \& Management Project: Phase I Final Report found that riparian lands perform four core ecological functions necessary for achieving the objectives of provincial water management policy: water quality protection; water storage and flood control; bank stabilization; and aquatic and terrestrial habitat. ${ }^{6}$ The report states that, "[i]n addition, these functions generate other societal benefits including recreational opportunities, increased capital value, improved aesthetics, shelter effects, cultural and spiritual values and ecotourism."

As wetlands and associated riparian lands are "lands" included as elements of the "aquatic environment" that provide many economical, social, and ecological goods and services to society $^{8}$ and indicate the health of Alberta's societal "common wealth," municipal councils might want to protect these lands in the overall greater public interest. Municipalities have an important role to play in maintaining, restoring, and enhancing Alberta’s current wetland and associated riparian land inventory. Unless municipal councils exercise their statutory authority to protect them, wetlands and associated riparian lands will continue to be

Wilson, Griffiths \& Anielski, ibid. See also Mark Anielski, The Economics of Happiness: Building Genuine Wealth (Gabriola Islands, B.C.: New Society Publishers, 2007), where the author identifies wetlands as one indicator of Alberta's "common wealth." Riparian Land Report, supra note 1 at 4 . The full text regarding core ecological functions reads:

A key goal of Alberta's riparian management system should be to maintain or restore the ecological functions and the associated environmental, social and economic benefits that healthy riparian lands provide society.

Although there is variability in the scientific literature on how riparian ecological functions are grouped, there is good agreement that riparian lands provide the following core ecological functions:

Water quality protection. This function includes cycling, filtration and retention of sediments, nutrients and other contaminants.

Water storage and flood control. This function consists of flood moderation (i.e., the slowing and storing of flood waters), stormwater runoff control and groundwater recharge.

Bank stabilization. This function involves reducing erosion, sediment transport and bank failures. Maintenance of this function may require meander belt protection (see Draft Nose Creek Water Management Plan 2006 for an explanation of meander belt protection).

Aquatic and terrestrial habitat. This function involves the maintenance of aquatic and terrestrial habitat including the provision of shade, food and woody debris to aquatic ecosystems, facilitation of plant and animal dispersal, and the provision of essential habitat for riparian-dependent species.

The maintenance of these core ecological functions is essential to achieving all three Water for Life outcomes:

- Safe, secure drinking water,

- Healthy aquatic ecosystems,

- Reliable quality water for a sustainable economy.

Ibid. at 4. See also Government of Alberta, Water For Life: Alberta's Strategy for Sustainability (Edmonton: Alberta Environment, 2003) [Water For Life].

8 See Government of Alberta, Framework for Water Management Planning (Edmonton: Alberta Environment, 2003) [Framework], especially the "Strategy for Protection of the Aquatic Environment" at 19. Wetlands and riparian lands are elements of the "aquatic environment" as defined in the Water Act, R.S.A. 2000, c.W-3, s. 1(1)(h), to mean: "the components of the earth related to, living in or located in or on water or the beds or shores of a water body, including but not limited to (i) all organic and inorganic matter, and (ii) living organisms and their habitat, including fish habitat, and their interacting natural systems." The Framework provides that the aquatic environment "includes naturally occurring features, such as rivers, streams, creeks, riparian areas, lakes, wetlands and groundwater” (at 20). “In fact, aquatic and riparian ecosystems support the greatest 'biological diversity' of all types of ecosystems" (at 19). Biological diversity is also defined in the Water Act, ibid, s. 8(1) as "the variability among living organisms and the ecological complexes of which they are a part, and includes diversity within and between species and ecosystems." 
negatively impacted; in many cases, these functioning landscapes may be lost forever from local, provincial, and national inventories, contrary to existing federal and provincial policies, laws, and regulations.

This article examines s. 60 of the Municipal Government $A c t^{9}$ as an existing municipal special power that grants broad authority to municipalities to manage local natural wetlands and associated riparian lands.

First, I define and review the importance of wetlands and associated riparian lands and briefly discuss some ownership issues.

Second, I provide a general overview of s. 60 of the MGA. As the authority to act granted in s. 60 is "subject to any other enactment," I briefly review constitutional doctrines and some recent case law that interprets consistency between municipal bylaws and provincial and federal enactments. Then, I address some of the more important federal and provincial legislation and policies that may supercede or provide guidance to municipal authority to pass bylaws and adopt policies and plans for water body management.

Third, I review the special municipal power granted in s. 60 for municipal "direction, control and management” of natural water bodies within municipal boundaries as an effective tool for managing human activities on, in, or near wetlands and associated riparian lands.

Finally, I conclude that s. 60 authorizes Alberta municipalities to enact municipal water body management bylaws and prepare water body management plans to manage human activities that may impact natural water bodies such as wetlands. Such bylaws and plans must be enacted and adopted for municipal purposes and address environmental matters of a local nature within municipal boundaries. The only limitation on such municipal action is that bylaws and plans must be consistent with provincial and federal laws, regulations, and statutory instruments.

\section{THE IMPORTANCE OF WETLANDS AND RIPARIAN LANDS}

\section{A. WetLandS}

Wetlands provide many ecological goods and services to society. The Provincial Wetland Compensation/Restoration Guide ${ }^{10}$ and the Alberta Water Council's (AWC) Recommendations for a New Alberta Wetland Policy ${ }^{11}$ both define wetlands as follows: "Wetlands are lands having water at, near, or above the land surface or which is saturated with water long enough to promote wetland or aquatic processes as indicated by poorly

Municipal Government Act, R.S.A. 2000, c. M-26 [MGA].

Government of Alberta, Provincial Wetland Compensation/Restoration Guide, Revised ed. (Edmonton: Alberta Environment, 2007) [Guide].

Alberta Water Council, Recommendations for a New Alberta Wetland Policy(Edmonton: Alberta Water Council, 2008) [New Alberta Wetland Policy]. 
drained (hydric) soils, hydrophytic vegetation, and various kinds of biological activity that are adapted to the wet environment."12

Wetlands are "lands.” The presence of water on these lands, during some period of time in each year, promotes wetland or aquatic processes and the development of certain types of soil and vegetation adapted to the wet environment. There are several kinds of wetlands in Alberta including sloughs and marshes, swamps, bogs, and fens. ${ }^{13}$ Unlike sloughs, which are primarily located in southern and central Alberta, swamps, bogs, and fens are common in Alberta's northern “Green Zone,” which consists primarily of public lands.

Although there is general agreement about when a wetland is "naturally occurring," 14 there is some controversy about when a wetland is "permanent." 15 The determination is important because Alberta Sustainable Resource Development (SRD) claims the beds and shores of permanent and naturally occurring wetlands as public lands, and describes "permanent" wetlands as ones that have permanent or continuous presence of water for seven to 12 months of the year. ${ }^{16}$

However, one hydrogeologist has suggested that the definition of wetland incorporates the meaning of permanent. According to him, a permanent wetland is a land location that exhibits wetland and aquatic processes, such as fluctuating levels of water from snow melt, precipitation, and groundwater recharge and discharge. The presence of certain soils and vegetation are indicators of wetland and aquatic processes and prove the location of a permanent wetland. The natural dynamic created by fluctuating water levels is required for a permanent wetland, not the continuous presence of water. ${ }^{17}$ The distinction is important

Ibid. at 4. See Government of Canada, The Federal Policy on Wetland Conservation (Ottawa: Minister of Supply and Services Canada, 1991) [The Federal Wetland Policy], where this definition first appeared.

$13 \quad$ See E.C. Pielou, Fresh Water (Chicago: University of Chicago Press, 1998) at 215 [footnotes omitted] for a description of different varieties of wetlands in Canada. Pielou states: "Wetlands are particularly abundant in regions having an immature drainage system, that is, where the drainage system is incompletely developed. This is true of the land that was covered by thick ice sheets during the last ice age. The 10,000 years or so - depending on the location - since the ice melted have not been enough for streams and rivers to erode a continuous, linked system of channels draining all the once-glaciated ground to the sea. Much undrained or ill-drained land still remains and is the site of numerous wetlands. That is why wetlands occupy so much more land in Canada than in the United States: nearly all of Canada was ice-covered."

14 See Guide, supra note 10 at iii for a definition of "naturally occurring" ("Naturally occurring wetland: an area where water has or does accumulate to water elevations documented to have occurred under natural conditions”). See also Kwasniak, “Alberta Crown Ownership,” supra note 4 at 80.

15 Kwasniak, “Alberta Crown Ownership,” ibid. at 80-85.

16 This information was taken from conversations and e-mails with Gerry Haekel, the Head of Riparian Land Management and Water Boundaries Unit with Lands Division of Alberta Sustainable Resource Development, from January 2006-November 2007. Gerry is a riparian management specialist. "His responsibilities include development of policy and management approaches involving shorelands (bed and shores of rivers, streams, and lakes), riparian lands, wetlands, and peatlands, as well as the assessment of waterbody ownership and boundaries": see online: Alberta Society of Professional Biologists <http://www.aspb. ab.ca/page_attachments/84/Directors_Bios_2008.pdf > . See also "Using Public Shorelands,” online: SRD <http://www.srd.gov.ab.ca/lands/usingpublicland/shorelands/ approvalsregulatoryrequirements.aspx $>$.

17 These comments derive from discussions with Jon Fennel of Worley Parsons Komex at the Legislation and Policy Committee meeting of the Bow River Basin Council in October 2007, while preparing a joint submission concerning the Alberta Water Council, Talking with Albertans About a New Wetland Policy and Implementation Plan (Edmonton: Alberta Water Council, 2007), online: Alberta Water Council $<$ http://www.waterforlife.gov.ab.ca>. See also Kwasniak, “Alberta Crown Ownership,” supra note 4 at 80-85, where she argues the same based on detailed statutory interpretation and legal analysis. See Despins v. St. Albert (City of), [1994] A.J. No. 1449 at para. 40 (Q.B.) (QL), aff'd [1996] A.J. No. 816 (C.A.), where the plaintiff challenged that the beds and shores of a large slough were private property, 
because municipalities may not appreciate that swampy or low-lying lands indicate flood prone areas where buildings and development may be at risk.

\section{B. RIPARIAN LANDS}

The environmental policy section of AENV recently recognized the importance of riparian lands to overall water supply and quality. They assembled a Riparian Land Conservation and Management Project Committee composed of provincial, municipal, and watershed stakeholders in the Calgary region to address depleting riparian lands in and around urban centres. The committee suggested the following definition in recognition of the important role riparian lands play in sustaining overall water supply, including groundwater recharge and discharge through springs and groundwater seeps: "Riparian land is any land that adjoins or directly influences a water body and includes floodplains and land that directly influences alluvial aquifers."18

Also, AENV conducted flyovers of the Calgary region in 2006-2007 to establish locations of significant wetlands and associated riparian lands and create baseline inventories to monitor for disturbance or restoration over time. ${ }^{19}$

\section{IMPORTANCE OF WETLANDS AND RIPARIAN LANDS}

Wetlands are lands that act as economical, natural infrastructure for water storage and retention and, in doing so, they provide flood attenuation. Wetland vegetation can provide high nutrient uptake that can purify water. Wetlands can also provide opportunities for groundwater recharge. They provide food and habitat for many indigenous fish, wildlife species, migratory birds, and endangered animals. As natural systems, wetlands may provide opportunities for passive and active recreation. ${ }^{20}$

Riparian lands are productive natural systems that provide shelter, food, and water for wildlife and domestic animals. Riparian vegetation and soils include layers of trees, shrubs, grasses, plants, organic, and inorganic materials, all of which interact together and act as a natural sponge during spring snow melt, flood events, and heavy rainfall. These lands improve water quality in water bodies by capturing sediment and contaminants as water

and claimed that the City of St. Albert's use of the slough as a park and for storm water management deprived the owner of ability to alienate. The Court held that the slough was "a naturally occurring lake formed by geological processes and is a permanent, naturally occurring body of water with well-defined banks.” Therefore, the beds and shores were Crown owned under the Public Lands Act, R.S.A. 2000, c. P-40, s. 3. In a subsequent attempt by the same plaintiff to have the matter reheard based on new evidence, Despins v. St. Albert (City of), 2004 ABQB 328, 358 A.R. 262 at para. 30, Fraser J. had this to say about whether any body of water in Alberta could be considered "permanent" for the purpose of the Public Lands Act: "It is to be presumed that the Legislature intended the provisions of the Public Lands Act (Alberta) to apply to those bodies of water in Alberta that can be considered 'permanent' as that term is commonly understood, notwithstanding that, from a strictly scientific point of view, there may be no such bodies of water in the province.” The 2004 action was dismissed as res judicata.

Riparian Land Report, supra note 1 at 3 [footnotes omitted].

Calgary, Strathmore, Cochrane, and the Municipal District of Rocky View have received maps from the Province that include data collected from the flyovers.

$20 \quad$ Pielou, supra note 13. See also Calgary Wetland Conservation Plan, supra note 4 at 30-31, App. 7. For an overview of wetland functions and how to place a numerical "value" on these ecological complexes, see Nancy Olewiler, The Value of Natural Capital in Settled Areas of Canada (British Columbia: Ducks Unlimited Canada \& Nature Conservancy of Canada, 2004). 
drains off adjacent lands. Well vegetated riparian lands control erosion of stream banks and shorelines during seasonal and high storm water runoff events by absorbing and, therefore, slowing the rate of flow. ${ }^{21}$ Riparian lands are important recreational areas for people of all ages, providing public access to the beds and shores of water bodies.

\section{WETLAND AND RIPARIAN LAND OWNERSHIP ISSUES}

The beds and shores of wetlands and their associated riparian lands located within a municipality may be owned by the federal, provincial, or municipal government; by irrigation districts as lands adjacent to or part of their works or distribution systems; by private landowners; or by other organizations such as land trusts or conservation groups. ${ }^{22}$ Water contained within wetlands or aquifers underlying riparian lands is always Crown owned.

Federal and provincial lands are Crown lands. Provincial law, including the MGA, cannot regulate and control the use and development of Crown lands unless the Province or the federal government agrees that the law applies, or specifically states that certain legislation applies to provincial or federal lands. For example, the Town of Banff, located within a national park, is a municipality governed under the MGA by agreement between the Province and the federal government.

The MGA specifically restricts the application of the $M G A$ to "municipalities and improvement districts," and, furthermore, the MGA does not specifically bind the Crown. The federal Crown is immune from the application of provincial laws, and s. 14 of the Alberta Interpretation Act provides that “[n]o enactment is binding on Her Majesty or affects Her Majesty or Her Majesty’s rights or prerogatives in any manner, unless the enactment expressly states that it binds Her Majesty."23

"Municipal lands" are lands that become the property of a municipal corporation through the subdivision process, or lands that the municipal corporation has purchased or otherwise legally acquired. Municipalities own and control the use and development of municipal lands, which typically consist of dedicated reserves, public utility corridors, local roads and pathways, and other parcels. Municipal reserves, municipal and school reserves, and environmental reserves are examples of municipal lands acquired during the subdivision process. ${ }^{24}$ Riparian lands owned by the municipality might be found in these reserve lands,

Riparian Land Report, supra note 1 at 4 . See also Lorne Fitch \& Norine Ambrose, Riparian Areas: A User's Guide to Health (Lethbridge: Cows and Fish Program, 2003); Lorne Fitch, Barry Adams, \& Kerri O’Shaughnessy, Caring for the Green Zone: Riparian Areas and Grazing Management, 3d ed., (Lethbridge: Cows and Fish Program, 2003) at 3; Bow River Project, Protecting Riparian Areas: Creative Approaches to Subdivision Development in the Bow River Basin (Airdrie: Bow River Project, 2002) at $11-13$

22 Kwasniak, "Alberta Crown Ownership," supra note 4. See also Environmental Protection and Enhancement Act, R.S.A. 2000, c. E-12 [EPEA]; “The Canada Ecological Gifts Program,” online: Environment Canada <http://www.cws-scf.ec.gc.ca/egp-pde> (provides tax incentives to private landowners to work with conservation groups to conserve environmentally sensitive lands).

23 R.S.A. 2000, c. I-8, s. 14. See Canada National Parks Act, S.C. 2000, c. 32, Sch. 1; Parks Town Act R.S.A. 2000, c. P-2. Banff is governed by both federal and provincial legislation, and the Town of Banff was incorporated by agreement that came into effect on 1 January 1990. The planning and development provisions in the MGA apply to Banff, pursuant to provisions in the agreement.

24 See MGA, supra note 9, ss. 661-77. These provisions deal with dedication of lands during the subdivision process, including the dedication of lands for roads and public utilities, municipal reserves, school reserves, and environmental reserves. The sections provide for percentages of land that can be required to be dedicated from a parcel under certain circumstances and limit when reserves can be 
or in municipal rights-of-way, or they might be dedicated by private landowners or deliberately purchased by the municipality for conservation.

Riparian lands in the White Zone are often privately owned, especially in rural areas. Unauthorized uses of municipal property, such as extending gardens or creating pathways to the shore through municipal or environmental reserves, can be controlled by a municipality through land use bylaw regulations or a stand-alone reserve bylaw. ${ }^{25}$

\section{E. THE EXTENT OF RIPARIAN LANDS IS Not AlWAys OBVIOUS}

The extent of riparian land adjacent to a lake, river, stream, or water body is often referred to as a "riparian zone." ${ }^{26}$ Riparian lands do not occur adjacent to a water body in concentric circles or within equidistant "strips" or "corridors" from the banks. The riparian zone depends on soils, underground geology, escarpments, groundwater formations, etc. This is important because during subdivision of private lands some Alberta municipalities only require dedication of a minimum six-metre strip of "environmental reserves" from the banks of a watercourse or water body without any scientific determination of the extent of riparian land necessary to prevent pollution or provide access to the bed and shore. The actual riparian zone adjacent to a watercourse or water body is best determined scientifically by a qualified water and aquatic environment specialist (QWAES). ${ }^{27}$

\section{OVERVIEW OF SECTION 60 OF THE MUNICIPAL GOVERNMENT ACT}

\section{A. Section 60 is "SubJect to Any Other EnActment"}

Section 60 grants "special municipal powers” authorizing municipal “direction, control and management” of "natural bodies of water” within municipal boundaries:

(1) Subject to any other enactment, a municipality has the direction, control and management of the rivers, streams, watercourses, lakes and other natural bodies of water within the municipality, including the air space above and the ground below.

(2) Nothing in this section gives a municipality the direction, control and management of mines and minerals. $^{28}$

required. Both the use and the disposition of reserve lands are restricted by these provisions. Municipal reserves and school reserves have prescribed uses. Environmental reserves may be maintained in their natural state or used as public parks. A municipality may decide to use environmental reserves for roads and certain utilities, or to maintain them in their natural state.

25 See Judy Stewart, Template of Land Use Bylaw Regulations for the Protection of Natural Environment Features and Water Resources including Wetlands, Riparian Lands and Reserve Lands (Calgary: Bow River Basin Council, 2008), online: Bow River Basin Council <http://www.brbc.ab.ca/pdfs/080507 Land\%20Use\%20Bylaw\%20Template-April\%2030\%202008\%20Final.pdf> (includes sample "reserve" regulations). See also Strathcona County, By-law No. 8-2007, Unauthorized Use of County Property Bylaw (10 May 2007).

26 See Riparian Areas: Environmental Uniqueness, Functions, and Values, NRCS/RCA Issue Brief 11 (Washington, D.C.: U.S. Department of Agriculture, 1996). See also ibid. Strips of land adjacent to water bodies may only be required to be dedicated to prevent pollution or provide public access to the bed and shore, as per the MGA, supra note 9, s. 664(1)(c).

$27 \quad$ Guide, supra note 10 at iii.

28 MGA, supra note 4, s. 60 [emphasis added]. 
Municipalities are creatures of the Province and have delegated authority. All municipal bylaws, including land use bylaws, are subject to the MGA and any other enactment, unless the $M G A$ or another enactment states otherwise. ${ }^{29}$

The MGA defines “enactment” as:

(i) an Act of the Legislature of Alberta and a regulation made under an Act of the Legislature of Alberta, and

(ii) an Act of the Parliament of Canada and a statutory instrument made under an Act of the Parliament of Canada,

but does not include a bylaw made by a council. ${ }^{30}$

Section 13 of the MGA clarifies that "[i]f there is an inconsistency between a bylaw and this or another enactment, the bylaw is of no effect to the extent of the inconsistency." ${ }^{31}$

Municipalities have general jurisdiction to pass bylaws for “municipal purposes”32 pursuant to Part 2 of the MGA, and specific powers for passing bylaws related to planning and development are granted in Part 17. (It should be noted that there are activities and land use and development operations within municipal boundaries, such as intensive feedlot

Ibid., s. 13. Inconsistency is determined by the courts when a bylaw is challenged as being ultra vires municipal powers. A bylaw that enhances, but does not result in "impossibility of dual compliance" with provincial or federal enactments is not necessarily inconsistent: see R. v. Greenbaum, [1993] 1 S.C.R. 674 [Greenbaum]; 114957 Canada Ltée (Spraytech, Société d'arrosage) v. Hudson (Town of), 2001 SCC 40, [2001] 2 S.C.R. 241 [Spraytech]; Croplife Canada v. Toronto (City of) (2005), 254 D.L.R. (4th) 40 (Ont. C.A.), leave to appeal to S.C.C. refused, 349 N.R. 198 [Croplife]; United Taxi Drivers' Fellowship of Southern Alberta v. Calgary (City of), 2004 SCC 19, [2004] 1 S.C.R. 485 [United Taxi] for tests to determine if a municipality has statutory authority to pass bylaws, or if a bylaw is inconsistent with federal or provincial laws rendering it inoperative. See also Peacock v. Norfolk (County of) (2006), 269 D.L.R. (4th) 45 at para. 26 (Ont. C.A.)[Peacock]. In that case, the majority held:

The leading authority on reconciling overlapping provincial statutes and municipal by-laws is the

Supreme Court of Canada's decision in Spraytech.... In that case, the court upheld the Town of Hudson's by-law regulating the use of pesticides despite the existence of provincial legislation in that field. After recognizing that in environmental matters the precautionary principle should apply, the majority of the court applied the impossibility of dual compliance test, taken from the federal-provincial context, to the provincial-municipal context. The Court commented that there was a fine line between laws that legitimately complement each other and those that invade another government's protected legislative sphere. At para. 38, the Court held the impossibility of dual compliance test requires first, that the municipal by-law deal with a similar subject as the provincial statute, and then that "obeying one necessarily means disobeying the other." Only then can the court find that a municipal by-law is inconsistent with a provincial statute. The court held that as a general principle, "the mere existence of provincial or federal legislation in a given field does not oust municipal prerogatives to regulate the subject-matter” (para. 39). However, the Court also stipulated that the impossibility of dual compliance test would not apply when, as in the present case, the relevant provincial legislation specifies a different test (para. 36).

According to the decision in Peacock, s. 13 of the MGA specifies a different test than impossibility of dual compliance.

MGA, ibid., s.1(1)(j) [emphasis added].

Ibid., s. 13.

Ibid., s. 3 ("the purposes of a municipality are (a) to provide good government; (b) to provide services, facilities or other things that, in the opinion of council, are necessary or desirable for all or a part of the municipality and (c) to develop and maintain safe and viable communities”). I argue that healthy functioning wetlands and riparian lands are necessary for safe and viable communities because they provide ecological goods and services like surface water and ground water purification, flood attenuation, ground water recharge and discharge, etc. 
operations, mining, and oil and gas operations that are regulated by other provincial legislation where the $M G A$, or parts of the $M G A$, do not apply.) ${ }^{33}$

Section 6 of the MGA also grants municipalities "natural person powers" as follows: "A municipality has natural person powers, except to the extent that they are limited by this or any other enactment." ${ }^{34}$ In Belland, ${ }^{35}$ the Alberta Court of Appeal discussed natural person powers in relation to s. 13 , the inconsistency provision. The Court held that the County was entitled to an injunction under s. 554 of the MGA restraining the Bellands from obstructing a road allowance on their property, even though the County had no bylaw in place to prohibit obstructions. Justice Slatter relied on the County's authority to enforce the Public Highways Development Act. ${ }^{36} \mathrm{He}$ interpreted the definition of "highway," which includes road allowances, and "highway authority," which includes municipalities, and held that s. 43 of the Public Highways Development Act was an enactment that the County was "authorized to enforce” under s. 554 of the $M G A .{ }^{37}$ When discussing matters of jurisdiction, Slatter J.A. explained the relationship of municipal natural person powers to other provisions in the $M G A$, including the inconsistency provision:

The M.G.A. also defines how the natural person powers of a municipality interact with its power to make bylaws. Section 180(2) states that when a municipality is authorized to do something by bylaw "it may only be done by bylaw". However, s. 11(1) makes it clear that the power to act by bylaw is in addition to, and not a limitation on, all of the powers of a natural person. If a municipality wishes to do something that a natural person could do, the municipality may do it in any manner that a natural person could. It is only where a municipal government is granted a power to do by bylaw something that a natural person could not do, that the power must be exercised by bylaw. ${ }^{38}$

Section 180 is also important to interpreting municipal natural person powers to pass bylaws:

180(1) A council may act only by resolution or bylaw.

Ibid. Part 17 of the MGA enables regulation and control of land use and development of private lands within municipal boundaries to achieve the purposes of Part 17. Some land use and development activities are regulated and controlled by other government enactments, departments, and agencies and Part 17 does not apply. See ss. 618, 618.1, and 619 for non-application of Part 17, exemptions, and other authorization provisions that describe activities and developments governed by other enactments. Notable exemptions are development or a subdivision effected only for: a highway or road; a well or battery with the meaning of the Oil and Gas Conservation Act, R.S.A., 2000, c. O-6; or a pipeline or an installation or structure incidental to the operation of a pipeline. Part 17 does not apply to Métis settlements or a designated area of Crown land in a municipal district or specialized municipality. The Lieutenant Governor in Council may, by regulation, exempt any action, person, or thing or all of them from the application of Part 17 and the regulations or bylaws created under Part 17. Development permits do not apply to confined feeding operations or manure storage facilities within the meaning of the Agricultural Operations Practices Act, R.S.A. 2000, c. A-7, if the feedlot or facility is approved under that Act. Other authorizations that prevail over any statutory plan, land use bylaw, subdivision decision, or development decision under Part 17 include licences, permits, approvals, and other authorizations granted by the Natural Resources Conservation Board, the Energy Resources Conservation Board, and the Alberta Energy Utilities Board. Conditions in a licence, permit, approval, or other authorization granted pursuant to an enactment by the government or government agencies prevail over conditions in a development permit.

MGA, ibid. s. 6.

St. Paul (County of) No. 19 v. Belland, 2006 ABCA 55, 380 A.R. 324 [Belland].

R.S.A. 2000, c. P-38.

Belland, supra note 35 at para. 28.

Ibid. at para. 15 . 
(2) Where a council or municipality is required or authorized under this or any other enactment or bylaw to do something by bylaw, it may only be done by bylaw.

(3) Where a council is required or authorized under this or any other enactment or bylaw to do something by resolution or to do something without specifying that it is to be done by bylaw or resolution, it may be done by bylaw or resolution. ${ }^{39}$

As stated by Slatter J.A., s. 11 falls within Part 2, Division 1 of the MGA and clarifies that a municipality's power to act under its general jurisdiction to pass bylaws "is in addition to" a municipality's power to act as a natural person. ${ }^{40}$ This makes sense because a natural person is not entitled to pass bylaws; however,

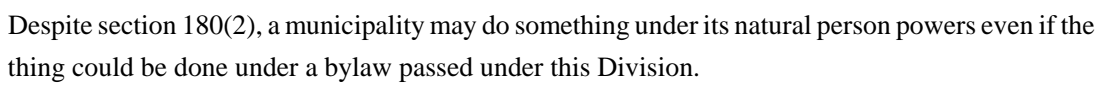

(2) Section 7(i) does not apply to a bylaw passed under a municipality’s natural person powers. ${ }^{41}$

Clearly, a bylaw enacted under the authority of s. 60 needs to be consistent with federal and provincial laws and regulations or the bylaw will be of no effect to the extent of the inconsistency. ${ }^{42}$ It is important to understand the concept of "inconsistency" and "operational conflict” between municipal bylaws and other enactments.

\section{B. INCONSISTENCY AND OPERATIONAL CONFLICT BETWEEN BYLAWS AND ENACTMENTS}

In Huot, ${ }^{43}$ the Quebec Superior Court clarified "inconsistency”: “A finding that a municipal by-law is inconsistent with a provincial statute (or a provincial statute with a federal statute) requires, first, that they both deal with similar subject matters and, second, that obeying one necessarily means disobeying the other." 44

In Re Attorney-General for Ontario and City of Mississauga, ${ }^{45}$ Morden J.A. for the majority of the Ontario Court of Appeal held that "a by-law is not void or ineffective merely because it 'enhances' the statutory scheme of a regulation by imposing higher standards of control than those in the related statute. This is not conflict or incompatibility per se."46

In Multiple Access, ${ }^{47}$ Dickson J. (as he then was) reviewed conflict between federal and provincial legislation and stated what is now known as the "impossibility of dual

$39 \quad$ MGA, supra note 9, s. 180.

$40 \quad$ Belland, supra note 35 at para. 15.

41 MGA, supra note 9, s. 11 (section 7(i) grants general jurisdiction to pass bylaws to enforce bylaw provisions made under the $M G A$ and any other enactment. Natural persons cannot enforce bylaw violations).

42 Ibid., s. 13 reads as follows: "If there is an inconsistency between a bylaw and this or any other enactment, the bylaw is of no effect to the extent of the inconsistency."

43 Huot c. St. Jerome (Ville de) (1993), J.E. 93-1052 (Sup. Ct.) [Huot].

$44 \quad$ Ibid. at para. 40, as cited in Spraytech, supra note 29 at para. 38. See Peacock, supra note 29 at paras. 38-60 for interpretation of "same subject matter."

(1981), 124 D.L.R. (3d) 385 (Ont. C.A.).

Ibid. at 400.

Multiple Access Ltd. v. McCutcheon, [1982] 2 S.C.R. 161 [Multiple Access]. 
compliance" test ${ }^{48}$ to determine if there is inconsistency or operational conflict between enactments: "there would seem to be no good reasons to speak of paramountcy and preclusion except where there is actual conflict in operation as where one enactment says 'yes' and the other says 'no'; 'the same citizens are being told to do inconsistent things'; compliance with one is defiance of the other." 49

In BC Lottery Corp., ${ }^{50}$ the British Columbia Court of Appeal applied the impossibility of dual compliance test "to examine an alleged provincial-municipal conflict"51 or inconsistency and stated: "A true and outright conflict can only be said to arise when one enactment compels what the other forbids." 52

In Spraytech, ${ }^{53}$ the majority of the Supreme Court of Canada determined that the Town of Hudson's pesticide bylaw enacted under the authority of Quebec's Cities and Towns Act ${ }^{54}$ was not in operational conflict with other enactments and, therefore, there was no inconsistency between the bylaw and the provincial and federal pesticide legislation. The majority decision reflected the application of the impossibility of dual compliance test established by Dickson J. in Multiple Access. In dissent, LeBel J. restated several administrative law principles from earlier Supreme Court of Canada decisions that a court might apply when determining if a bylaw is inconsistent or in operational conflict with an enactment before applying the impossibility of dual compliance test, as identified in Figure 1 , below.

\section{Figure 1: Administrative Law Operational Conflict Tests:}

\section{LeBel J. in Spraytech ${ }^{55}$}

\begin{tabular}{|l|l|l|}
\hline Principle & Case & Citation \\
\hline "Municipalities remain creatures of provincial legislatures" & Public School Boards' & 2000 SCC 45, \\
(at para. 49). & Assn. (Alberta) v. & [2000] 2 S.C.R. \\
& Alberta (Attorney & 409; 2001 SCC \\
& General); O.E.C.T.A. & 15, [2001] 1 \\
& v. Ontario (Attorney & S.C.R. 470. \\
\hline "Municipalities exercise such powers as are granted to them & Feneral) & \\
by legislatures" (at para. 49). & Centre Ltd. v. & [1985] 1 S.C.R. \\
& Montreal (City of); R. & S.C.R. 650. \\
\hline
\end{tabular}

Spraytech, supra note 29 at para. 36.

Multiple Access, supra note 47 at para. 48.

British Columbia Lottery Corp. v. Vancouver (City of), 1999 BCCA 18, 169 D.L.R. (4th) 141 [BC Lottery Corp.].

Spraytech, supra note 29 at para. 38.

BC Lottery Corp., supra note 50 at para. 20.

Spraytech, supra note 29.

R.S.Q. c. C-19.

Spraytech, supra note 29 at paras. 46-53. 


\begin{tabular}{|c|c|c|}
\hline Principle & Case & Citation \\
\hline $\begin{array}{l}\text { "It is not enough that a particular issue has become a } \\
\text { pressing concern in the opinion of a local community. This } \\
\text { concern must relate to problems that engage the community } \\
\text { as a local entity, not a member of the broader polity. It must } \\
\text { be closely related to the immediate interests of the } \\
\text { community within the territorial limits defined by the } \\
\text { legislature in a matter where local governments may usefully } \\
\text { intervene.... It does not allow local governments and } \\
\text { communities to exercise powers in questions that lie outside } \\
\text { the traditional area of municipal interests, even if municipal } \\
\text { powers should be interpreted broadly and generously” (at } \\
\text { para. 53). }\end{array}$ & $\begin{array}{l}\text { Shell Canada } \\
\text { Products Ltd. v. } \\
\text { Vancouver (City of) }\end{array}$ & $\begin{array}{l}\text { [1994] 1 S.C.R. } \\
231 .\end{array}$ \\
\hline $\begin{array}{l}\text { "If a local government body exercises a power, a grant of } \\
\text { authority must be found somewhere in the provincial laws. } \\
\text { Although such a grant of power must be construed } \\
\text { reasonably and generously" (at para. 49). }\end{array}$ & $\begin{array}{l}\text { Nanaimo (City of) v. } \\
\text { Rascal Trucking Ltd. }\end{array}$ & $\begin{array}{l}2000 \text { SCC 13, } \\
\text { [2000] 1 S.C.R. } \\
342 .\end{array}$ \\
\hline $\begin{array}{l}\text { "In the case of a specific grant of power, its limits must be } \\
\text { found in the provision itself. Non-included powers may not } \\
\text { be supplemented through the use of the general residuary } \\
\text { clauses often found in municipal laws" (at para. 52). }\end{array}$ & R. v. Greenbaum & $\begin{array}{l}\text { [1993] 1 S.C.R. } \\
674 .\end{array}$ \\
\hline $\begin{array}{l}\text { “...the applicable test to determine whether an operational } \\
\text { conflict arises is set out in Multiple Access.... There must be } \\
\text { an actual conflict, in the sense that compliance with one set } \\
\text { of rules would require a breach of the other.... The basic test } \\
\text { remains the impossibility of dual compliance” (at para. 56). }\end{array}$ & $\begin{array}{l}\text { Multiple Access Ltd. v. } \\
\text { McCutcheon; } \\
\text { M \& D Farm Ltd. v. } \\
\text { Manitoba Agricultural } \\
\text { Credit Corp. }\end{array}$ & $\begin{array}{l}\text { [1982] 2 S.C.R. } \\
\text { 161; [1999] } 2 \\
\text { S.C.R. } 961 .\end{array}$ \\
\hline
\end{tabular}

Following Spraytech, in Rothmans, ${ }^{56}$ the Supreme Court of Canada developed a two-part test to determine inconsistency or operational conflict within the federal "paramountcy doctrine." Rothmans challenged the validity of provincial tobacco control legislation in light of a federal enactment that addressed similar subject matter. The Supreme Court of Canada held that the provincial legislation was valid legislation; it was not inconsistent, nor did it frustrate the legislative purpose underlying the federal law. Justice Major, writing for a unanimous court, adopted impossibility of dual compliance as the first step in determining inconsistency or operational conflict within the paramountcy doctrine and added as follows: "However, subsequent cases indicate that impossibility of dual compliance is not the sole mark of inconsistency. Provincial legislation that displaces or frustrates Parliament's legislative purpose is also inconsistent for the purposes of the doctrine."57

Justice Major reviewed the Spraytech and Law Society of British Columbia v. Mangat ${ }^{58}$ cases and added: 
In my view, the overarching principle to be derived from the $M c C u t c h e o n$ and later cases is that a provincial enactment must not frustrate the purpose of a federal enactment, whether by making it impossible to comply with the latter or by some other means. In this way, impossibility of dual compliance is sufficient but not the only test for inconsistency.

It follows that in determining whether s. 6 of The Tobacco Control Act is sufficiently inconsistent with s. 30 of the Tobacco Act so as to be rendered inoperative through the paramountcy doctrine, two questions arise. First, can a person simultaneously comply with s. 6 of The Tobacco Control Act and s. 30 of the Tobacco Act? Second, does s. 6 of The Tobacco Control Act frustrate Parliament's purpose in enacting s. 30 of the Tobacco Act? ${ }^{59}$

In addition to the common law principles stated above, the $M G A$ provides statutory direction for a bylaw enacted under Part 2, Division 1 of the MGA: "general jurisdiction to pass bylaws" must be consistent with a bylaw regulating the same subject matter enacted under "specific bylaw passing powers" in an enactment other than Part 2, Division 1. If such bylaws are inconsistent, the bylaw passed pursuant to Part 2, Division 1 will have no effect to the extent of the inconsistency:

(1) In this section, “specific bylaw passing power” means a municipality’s power or duty to pass a bylaw that is set out in an enactment other than this Division, but does not include a municipality's natural person powers.

(2) If a bylaw could be passed under this Division and under a specific bylaw passing power, the bylaw passed under this Division is subject to any conditions contained in the specific bylaw passing power.

(3) If there is an inconsistency between a bylaw passed under this Division and one passed under a specific bylaw passing power, the bylaw passed under this Division is of no effect to the extent that it is inconsistent with the specific bylaw passing power. ${ }^{60}$

Part 17 of the MGA grants municipalities specific bylaw passing powers. Section 639 in Part 17 requires a municipality to pass a land use bylaw. Section 10(2) provides that if a council passes a bylaw under Part 2, Division 1 "that could be passed" under a specific bylaw passing power, such bylaw "is subject to any conditions contained in the specific bylaw passing power." ${ }^{\prime 1}$ Planning bylaws enacted under Part 17 have certain notice requirements and require three separate readings, with a public hearing before second reading of the bylaw. $^{62}$ If a council passes a bylaw for similar subject matter under Part 2, Division 1 that could be passed under Part 17, the notice and public hearing requirements would apply. If compliance with a Part 2 bylaw "compels what the other forbids" and "obeying one necessarily means disobeying another," and the Part 2 bylaw frustrates the purpose of the Part 17 bylaw, the bylaws may be held to be inconsistent. ${ }^{63}$ The Part 2 bylaw would be of no effect to the extent of the inconsistency.

\footnotetext{
59 Rothmans, supra note 56 at paras. 14-15

$60 \quad$ MGA, supra note 9 , s. 10.

Ibid., s. 10(2).

Ibid., s. 692.

Ibid., s. 10(3).
} 
A s. 60 municipal local water body management bylaw must be consistent with federal and provincial laws that regulate similar subject matter, such that there is no operational conflict as clarified by the Supreme Court of Canada in Rothmans. As well, provincial and federal policies for managing water bodies may provide guidance and direction for framing municipal bylaws for these lands located within municipal boundaries. Before examining some of the provincial and federal enactments that regulate and control land use or management of water bodies, it is important to review the Supreme Court of Canada decisions that followed Rothmans with respect to the paramountcy doctrine and other constitutional doctrines.

The interpretation of the "pith and substance" of bylaws and enactments that deal with similar subject matter, as well as the doctrines of interjurisdictional immunity, double aspect, and federal paramountcy, were recently clarified in two Supreme Court of Canada decisions: Canadian Western Bank ${ }^{64}$ and Lafarge ${ }^{65}$ released concurrently on 31 May 2007. In Lafarge, the Supreme Court of Canada was asked to determine if the City of Vancouver's "zoning and development” bylaw was applicable to Lafarge's development of an integrated ship offloading/concrete batching facility on waterfront property owned and managed by a Vancouver Port Authority (VPA), which was a federal undertaking constituted under the Canada Marine Act. ${ }^{66}$ The VPA and the City both supported the development as approved by the port authority according to a pre-existing plan. However, neighbourhood ratepayers brought an application to the British Columbia Supreme Court arguing that Lafarge required a development permit from the City. The VPA claimed that the development permit was not necessary and that the bylaw was inapplicable because the waterfront lands were "public property" owned by the federal government and, therefore, immune from municipal regulation and control pursuant to the doctrine of interjurisdictional immunity. ${ }^{67}$ The VPA argued further that the project was approved under the port authority's mandate to manage the port as a federal undertaking pursuant to s. 91(10) of the Constitution Act, $1867 .{ }^{68}$

The decision is important because, as clarified in the next section, the Navigable Waters Protection $A c t^{69}$ is one of the federal enactments that may impact a municipality's ability to manage natural water bodies if they are "navigable.” However, some recent amendments to that federal enactment exempt some municipal infrastructure installation and development activities from the previous need for federal approvals, which were historically required under the legislation.

\footnotetext{
64 Canadian Western Bank v. Alberta, 2007 SCC 22, [2007] 2 S.C.R. 3 [Canadian Western Bank]. British Columbia (Attorney General) v. Lafarge Canada, 2007 SCC 23, [2007] 2 S.C.R. 86 [Lafarge]. S.C. 1998 , c. 10. Lafarge, supra note 65, headnotes.

(U.K.), 30 \& 31 Vict., c. 3, s. 91(10), reprinted in R.S.C. 1985, App. II, No. 5 (exclusive power over "navigation and shipping").

R.S.C. 1985, c. N-22. But see recent amendments made through the Budget Implementation Act, S.C. 2009, c. 2, an omnibus bill tabled by the Conservative government on 6 February 2009 and assented to on 12 March 2009. The legislation will limit the applicability of the Navigable Waters Protection Act and speed up the approval process by "de-listing and de-classifying” municipal and provincial projects that might interfere with the right of navigation or the classification of the waters. The federal government would allow projects in certain waters without the requirement to have an environmental impact assessment completed.
} 
In 1978, the Ontario Court of Appeal stated in Hamilton Harbour ${ }^{70}$ that there may be concurrent or overlapping jurisdiction between federal and provincial regulations and controls of land use on land covered by water. That decision was adopted in 1995 in Galway, where Murphy J. made the following statement: "Municipalities have the power to pass bylaws to regulate matters on land covered by water provided they do not permit structures which would interfere with navigation. That is a federal jurisdiction."71

In Lafarge, the majority of the Supreme Court of Canada adopted Hamilton Harbour and applied principles of legal interpretation and constitutional doctrines similar to those applied in Canadian Western Bank, an Alberta insurance law case. ${ }^{72}$ In Canadian Western Bank, provincial insurance legislation was enacted to protect consumers and the Province claimed that it applied to federally chartered banks that promoted the sale of insurance products as part of their banking operations. The banks claimed interjurisdictional immunity under s. 91(15) of the Constitution Act, 1867. Although there was a strong dissent by Bastarache J. in both Canadian Western Bank and Lafarge, the majority decided the jurisdictional issues using a systematic interpretative approach loosely summarized as follows:

(a) determine the pith and substance;

(b) if both laws are intra vires, there are certain limited federal matters that may attract the doctrine of interjurisdictional immunity, but those should remain limited to matters where precedents already exist; and

(c) apply the paramountcy doctrine using the test for inconsistency as stated in Spraytech and clarified in Rothmans. The paramountcy doctrine will enable the courts to establish whether the provincial legislation is inconsistent with federal law and, if so, then the provincial legislation will be inoperative to the extent of the inconsistency.

In Canadian Western Bank, the Supreme Court of Canada stated the process for determining pith and substance as follows:

It is now well established that the resolution of a case involving the constitutionality of legislation in relation to the division of powers must always begin with an analysis of the "pith and substance" of the impugned legislation....

This initial analysis consists of an inquiry into the true nature of the law in question for the purpose of identifying the "matter" to which it essentially relates.... If the pith and substance of the impugned legislation can be related to a matter that falls within the jurisdiction of the legislature that enacted it, the courts will

Hamilton Harbour Commissioners v. City of Hamilton (1978), 91 D.L.R. (3d) 353(Ont. S.C.) [Hamilton Harbour]. Also see Hamilton Harbour Commissioners v. City of Hamilton (1976), 91 D.L.R. (3d) 353 at 378 (Ont. H.C.), where Griffiths J. stated: "In my opinion, land-use control within a harbour has both provincial and federal aspects.... Only if conflict arises with respect to the use of a parcel of land within the limits of the harbour, will the paramountcy of the federal power cause the operation of the by-law of the City to be suspended.”

$71 \quad$ Galway and Cavendish (Townships) v. Windover (1995), 130 D.L.R. (4th) 710 at 714 (Ont. Ct. J. (Gen. Div.)) [Galway].

Supra note 64. 
declare it intra vires. If, however, the legislation can more properly be said to relate to a matter that is outside the jurisdiction of that legislature, it will be held to be invalid to this violation of the division of powers.

To determine the pith and substance, two aspects of the law must be examined: the purpose of the enacting body, and the legal effect of the law... To assess the purpose, the courts may consider both intrinsic evidence, such as the legislation's preamble or purpose clauses, and extrinsic evidence, such as Hansard or minutes of parliamentary debates. ${ }^{73}$

The Supreme Court of Canada stated that the courts should determine the "dominant purpose" of the provincial law and affirmed that a law's "secondary objectives and effects have no impact on its constitutionality: 'merely incidental effects will not disturb the constitutionality of an otherwise intra vires law.' "74 The Supreme Court of Canada added that "[t]he 'pith and substance' doctrine is founded on the recognition that it is in practice impossible for a legislature to exercise its jurisdiction over a matter effectively without incidentally affecting matters within the jurisdiction of another level of government."75

Next, the Supreme Court of Canada provided that enactments may have a "double aspect" that will be identified through analysis of "pith and substance," which "recognizes that both Parliament and the legislatures can adopt valid legislation on a single subject depending on the perspective from which the legislation is considered, that is, depending on the various 'aspects' of the 'matter' in question.,"76

If the enactments are both intra vires, the doctrine of interjurisdictional immunity, which is a doctrine of "exclusivity," may apply in limited circumstances. However, the Supreme Court of Canada cautioned courts in applying the doctrine as a matter of course by stating emphatically that the doctrine is one of "limited application" and "not acceptable in the Canadian federal structure.”77 The Court continued:

\footnotetext{
A broad application also appears inconsistent ... with the flexible federalism that the constitutional doctrines of pith and substance, double aspect and federal paramountcy are designed to promote.... The Constitution, though a legal document, serves as a framework for life and for political action within a federal state, in which the courts have rightly observed the importance of co-operation among government actors to ensure that federalism operates flexibly. ${ }^{78}$
}

The Supreme Court of Canada then provided that if both enactments are determined to be intra vires, it must be determined if there is any operational conflict such that the

\footnotetext{
Ibid. at paras. 25-27.

Ibid. at para. 28.

Ibid. at para. 29.

Ibid. at paras. 30-31.

Ibid. at paras. 33,38 .

Ibid. at para. 42. See also para. 24:

The constitutional doctrines permit an appropriate balance to be struck in the recognition and management of the inevitable overlaps in rules made at the two levels of legislative power, while recognizing the need to preserve sufficient predictability in the operation of the division of powers. The doctrines must also be designed to reconcile the legitimate diversity of regional experimentation with the need for national unity. Finally, they must include a recognition that the task of maintaining the balance of powers in practice falls primarily to governments, and constitutional doctrine must facilitate, not undermine what this court has called "co-operative federalism.”
} 
paramountcy doctrine would apply. If there is no operational conflict, then both enactments remain in full force and effect. If operational conflict exists, and a provincial enactment is determined to be inconsistent with the federal enactment such that a person could not comply with both laws and the purpose of the federal legislation is frustrated, then the provincial enactment will be declared of no force and effect to the extent of the inconsistency.

The Lafarge case is important for the analysis of the operational conflict between a land use approval issued by the VPA pursuant to the authority granted in the Canada Marine Act under the federal power over "navigation and shipping” and a municipal land use bylaw that regulated and controlled the same waterfront lands. The Supreme Court of Canada applied the paramounty doctrine and rejected the VPA's claim of interjurisdictional immunity, but found operational conflict between the municipal bylaw and the federal power over navigation. However, the Supreme Court of Canada stated: “[t]he development of waterfront land could potentially fall under either provincial or federal jurisdiction, depending on the ownership and the use to which the land is proposed to be put. Waterfront lands do not cease to be 'within the province' by reason of their potential use for federally regulated activities."

Later the Court added: "[i]n the absence of valid and applicable federal regulatory land use controls, there would be no regulatory vacuum on the ... site. The provincial land-use controls would apply." 80

Several provincial cases followed (or were determined at the same time as Canadian Western Bank and Lafarge) wherein municipal land use bylaw provisions that regulated and controlled buildings and development on waterfront properties within navigable waters were challenged as ultra vires. ${ }^{81}$ Overall, the provincial cases adopted the principles and doctrines in Lafarge. Two of these cases are relevant to the discussion of municipal bylaws to manage water bodies such as wetlands, as well as whether municipal bylaws apply to regulate and control buildings and land development in waterfront or on lands adjacent to navigable waters. In Salt Spring Island Local Trust, ${ }^{82}$ heard after Lafarge, the British Columbia Court of Appeal was asked to determine whether the municipal land use bylaw applied to restrict the renovations of a "floating structure" in Ganges Harbour. The British Columbia Court of Appeal adopted the three step approach provided by the Supreme Court of Canada, stating that the doctrine of interjurisdictional immunity must be applied with restraint. The Court found that the pith and substance of the land use bylaw was property and civil rights within the province of British Columbia and that no operational conflict existed because there was no conflicting federal legislation in place:

Merely because an object physically fits the definition of "ship" or "vessel” does not engage the federal power over navigation. That power does not operate as an abstract concept. It functions in the real world.

Lafarge, supra note 65 at para. 37.

Ibid. at para 73.

See e.g. North Pender Island Trust Committee v. Hunt, 2008 BCSC 391, 82 B.C.L.R. (4th) 124 [North Pender Island Trust]; Salt Spring Island Local Trust Committee v. B \& B Ganges Marina Ltd., 2008 BCCA 544, 303 D.L.R. (4th) 398 [Salt Spring Island Trust]; Morrison v. Halifax (Regional Municipality), 2008 NSSC 375, 271 N.S.R. (2d) 383; Ramara (Township) v. Guettler (2007), 33 M.P.L.R. (4th) 257 (Ont. Sup. Ct. J.). 
As has been said, the federal power over navigation and shipping is not a power over ships. Its focus is on the activities of shipping and navigation. According to the Concise Oxford English Dictionary, 11th ed., "navigation" is "the process or activity of navigating”. In the circumstances of this case, I would not extend the reach of the federal power over navigation to emasculate the provincial power to regulate buildings and structures merely because they float and physically meet the definition of a ship. ${ }^{83}$

In North Pender Island Trust, Bracken J. for the Supreme Court of British Columbia adopted the lower court decision in Salt Spring Island Trust and stated that Pender Island Trust "has the power to pass zoning bylaws regulating the use of water as well as land." ${ }^{4}$ Although North Pender Island Trust was decided before the British Columbia Court of Appeal decision in Salt Spring Island Trust, the decision was not affected.

In Alberta, an argument could be made that municipalities have jurisdiction to regulate and control land use of all "land," including watercourses, which are the beds and shores, or the locations, of water bodies. Land is not defined in the MGA, but it is defined in the Land Titles Act as follows:

\begin{abstract}
"[L]and” means land, messuages, tenements and hereditaments, corporeal and incorporeal, of every nature and description, and every estate or interest therein, whether the estate or interest is legal or equitable, together with paths, passages, ways, watercourses, liberties, privileges and easements appertaining thereto and trees and timber thereon, and mines, minerals and quarries thereon or thereunder lying or being, unless any of them are specially excepted. ${ }^{85}$
\end{abstract}

Watercourse is broadly defined in the Environmental Protection and Enhancement Act as follows: "(i) the bed and shore of a river, stream, lake, creek, lagoon, swamp, marsh or other natural body of water, or (ii) a canal, ditch reservoir or other artificial feature made by humans, whether it contains or conveys water continuously or intermittently." ${ }^{\text {"8 }}$

\title{
C. Federal and Provincial Laws and Policies That May Apply
}

Even though there is the body of common law supporting municipal bylaws that may overlap with provincial and federal laws to regulate and control waterfront developments, municipal regulations and controls must be consistent with existing provincial and federal enactments that legislate similar subject matter. Therefore, it is important to note a number of enactments that may apply to limit the authority of a municipality to manage human activities or uses of water bodies, specifically wetlands and associated riparian lands within municipal boundaries. For example:

- $\quad$ the Water Act, ${ }^{87}$ administered by AENV, applies because the Province owns the surface water in the wetlands and the groundwater underlying riparian lands, and regulates water diversion, water use, and activities that disturb water;

$83 \quad$ Ibid. at para. 73.

$84 \quad$ North Pender Island Trust, supra note 81 at para. 51 [emphasis added].

$85 \quad$ R.S.A. 2000, c. L-4 , s. $1(\mathrm{~m})$.

86 EPEA, supra note 22, s. 1(yyy).

Supra note 8. 
- $\quad$ the $E P E A,{ }^{88}$ also administered by AENV, applies because it regulates water intakes and treatment facilities, potable water wells and private septic systems, storm water and waste water outfalls, pesticide applications, etc.;

- $\quad$ the Public Lands Act, ${ }^{89}$ administered by SRD, applies because the Province owns the beds and shores of permanent and naturally occurring wetlands, and regulates dispositions of the beds and shores and the construction of temporary structures, such as boat docks;

- $\quad$ the Fisheries Act, ${ }^{90}$ administered by the Department of Fisheries and Oceans (DFO), applies because it regulates deleterious substances, including road salt and sediments found in urban runoff that may harm fish habitat;

- $\quad$ the Canada Shipping Act, 2001, ${ }^{91}$ administered by Transport Canada, applies because it regulates recreational boating; and

- $\quad$ federal enactments that protect navigability and habitat for migratory birds and endangered species may also apply. ${ }^{92}$

The federal and provincial laws noted above all limit and regulate municipal roles and responsibilities to some extent, and provincial policy documents provide guidance to municipalities exercising the authority granted in s. $60 .^{93}$

The most important federal and provincial laws that regulate human activities or development of wetlands and associated riparian lands in Alberta's White Zone are included in Figure 2, in which I highlight each law and discuss the most relevant provincial and federal policies and programs.

$89 \quad$ Supra note 17, s. 3. The Province does not own the beds and shores of wetlands on federal land. See Kwasniak, "Alberta Crown Ownership, supra note 4 at 62; Constitution Act, 1867, supra note 68, s. 91(1)(A). The Public Lands Act will be extensively amended by the Alberta Land Stewardship Act, S.A. 2009, c. A-26.8 [ALSA], which introduces regional planning and mandates that municipal land use plans and land use bylaws be consistent with regional land use plans.

$90 \quad$ R.S.C. 1985 , c. F-14.

91 S.C. 2001, c. 26 [Canada Shipping Act].

92 See the Navigable Waters Protection Act, supra note 69. The federal Department of Fisheries and Oceans (DFO) may be involved if the proposed development interferes with navigability of a navigable water body. Activities that impact nesting or other habitat used by migratory birds and endangered species are also regulated by federal laws: see Migratory Birds Convention Act, 1994, S.C. 1994, c. 22 [Migratory Birds Convention Act]; Species at Risk Act, S.C. 2002, c. 29. Recently, Environment Canada used the enforcement provisions under the Migratory Birds Convention Act to fine Canadian National Railway for releases of contaminants into water bodies used by migratory birds for nesting and food in both British Columbia and Alberta. As well, the same legislation was used to fine Syncrude for dumping toxins in tailing ponds near Fort McMurray killing 1,600 ducks. In March 2009, the federal government introduced the Environmental Enforcement Act, S.C. 2009, c. 14, which will authorize significant monetary penalties for offences committed under six federal environmental laws including the Migratory Birds Convention Act.

$93 \quad$ See e.g. Interim Wetland Policy, supra note 1; Water For Life, supra note 7; Land Use Policies (Edmonton: Alberta Municipal Affairs, 1996). See also supra notes 1, 7, 10. 


\section{Figure 2: Federal and Provincial Legislation Affecting Municipal Management of Wetlands and Riparian Lands in Alberta's White Zone ${ }^{94}$}

\begin{tabular}{|c|c|}
\hline Legislation & Purpose \\
\hline $\begin{array}{l}\text { Canada Water Act, R.S.C. } \\
\text { 1985, c. C-11. }\end{array}$ & $\begin{array}{l}\text { The federal government may enter into agreements and projects with the } \\
\text { provincial government, which could include wetland conservation. Currently } \\
\text { used to enable joint flood control and agricultural water projects. }\end{array}$ \\
\hline $\begin{array}{l}\text { Canada Shipping Act, } \\
\text { 2001, S.C. 2001, c. } 26 .\end{array}$ & $\begin{array}{l}\text { Regulates all aspects of recreational boating. Minister of Transport is } \\
\text { responsible for administration of the Act. }\end{array}$ \\
\hline $\begin{array}{l}\text { Fisheries Act, R.S.C. } \\
\text { 1985, c. F-14. }\end{array}$ & $\begin{array}{l}\text { Defines "deleterious substances" and regulates activities that might result in } \\
\text { the "harmful alteration, disruption or destruction of fish habitat" (ss. 34-35). }\end{array}$ \\
\hline $\begin{array}{l}\text { Migratory Birds } \\
\text { Convention Act, 1994, } \\
\text { S.C. 1994, c. } 22 .\end{array}$ & $\begin{array}{l}\text { Regulates activities that could harm migratory birds or their nests and } \\
\text { prohibits deposits of certain materials that might be harmful in water } \\
\text { frequented by migratory birds. }\end{array}$ \\
\hline $\begin{array}{l}\text { Navigable Waters } \\
\text { Protection Act, R.S.C. } \\
\text { 1985, c. N-22. }\end{array}$ & $\begin{array}{l}\text { Regulates uses and activities of water that may interfere with navigation on } \\
\text { navigable waters. }\end{array}$ \\
\hline $\begin{array}{l}\text { Species at Risk Act, S.C. } \\
\text { 2002, c. } 29 .\end{array}$ & $\begin{array}{l}\text { Prohibits the destruction of critical habitat for species at risk. Provides } \\
\text { stewardship opportunities of critical habitat. Prohibits killing, harming, or } \\
\text { harassing endangered species as defined. }\end{array}$ \\
\hline $\begin{array}{l}\text { Environmental Protection } \\
\text { and Enhancement Act, } \\
\text { R.S.A. 2000, c. E-12. }\end{array}$ & $\begin{array}{l}\text { Regulates municipal water, waste water and storm water systems, groundwater } \\
\text { wells, private waste water systems, waste management, pesticides, etc. } \\
\text { Provides for conservation easements. See also: Pesticide Sales, Handling, Use } \\
\text { and Application Regulation, Alta. Reg. 24/1997; Alberta Environment, Code } \\
\text { of Practice for Pesticides (Edmonton: Alberta Environment, 1997). }\end{array}$ \\
\hline $\begin{array}{l}\text { Land Titles Act, R.S.A. } \\
\text { 2000, c. L-4. }\end{array}$ & $\begin{array}{l}\text { Provides for boundary changes when the "natural boundary" changes through } \\
\text { erosion or accretion when the title to lands is a "natural boundary." Public } \\
\text { lands are excluded from titles: see also Law of Property Act, R.S.A. 2000, c. } \\
\text { L-7. }\end{array}$ \\
\hline $\begin{array}{l}\text { Municipal Government } \\
\text { Act, R.S.A. 2000, c. M-26. }\end{array}$ & $\begin{array}{l}\text { Provides for municipal bylaw passing powers (Part 2), municipal “direction, } \\
\text { control and management” of natural water bodies (s. 60), and planning and } \\
\text { development of all private and municipal lands within municipal boundaries. } \\
\text { (Part 17). The MGA governs municipal corporations. Also see the Safety } \\
\text { Codes Act, R.S.A. 2000., c. S-1, which appends the Plumbing Code } \\
\text { Regulation, Alta. Reg. 119/2007, and the Building Code Regulation, Alta. } \\
\text { Reg. 117/2007. The Subdivision and Development Regulation, Alta. Reg. } \\
43 / 2002 \text { also affects development of private lands. See also municipal } \\
\text { statutory plans, land use bylaws, and other municipal bylaws that prohibit, } \\
\text { regulate, or control activities in Part } 2 \text {. }\end{array}$ \\
\hline
\end{tabular}

94 Judy Stewart, Cooperation, Coordination, Integration: Buffalo Lake Integrated Shoreland Management Plan - Review for Implementation Report (Edmonton: Government of Alberta, 2008) at 22-23 [Stewart, "Cooperation, Coordination, Integration"]. 


\begin{tabular}{|c|c|}
\hline Legislation & Purpose \\
\hline $\begin{array}{l}\text { Public Lands Act, R.S.A. } \\
\text { 2000, c. P-40. }\end{array}$ & $\begin{array}{l}\text { Regulates the use and development of provincial public lands, including the } \\
\text { beds and shores of all permanent and naturally occurring water bodies in } \\
\text { Alberta. }\end{array}$ \\
\hline $\begin{array}{l}\text { Surveys Act, R.S.A. 2000, } \\
\text { c. S-26. }\end{array}$ & $\begin{array}{l}\text { The legal bank of a wetland is established by surveyors pursuant to the Act. } \\
\text { The legal bank establishes the delineation of beds and shores of permanent and } \\
\text { naturally occurring water bodies owned by the Province. }\end{array}$ \\
\hline $\begin{array}{l}\text { Water Act, R.S.A. 2000, c. } \\
\text { W-3. }\end{array}$ & $\begin{array}{l}\text { "The property in and the right to the diversion and use of all water in the } \\
\text { Province is vested in Her Majesty in right of Alberta except as provided for in } \\
\text { the regulations" (s. 3(2)). Diversion and use of water is regulated. Water } \\
\text { management planning is a component of the legislation. Disturbance of water } \\
\text { bodies (such as draining and filling of wetlands) is an activity under the Act } \\
\text { that requires an approval. }\end{array}$ \\
\hline $\begin{array}{l}\text { Weed Control Act, R.S.A. } \\
\text { 2000, c.W-5. }\end{array}$ & $\begin{array}{l}\text { Municipalities are delegated authority to pass local bylaws to control } \\
\text { restricted, noxious, and nuisance weeds on municipal lands and on certain } \\
\text { public lands such as highway corridors. }\end{array}$ \\
\hline $\begin{array}{l}\text { Wildlife Act, R.S.A. 2000, } \\
\text { c.W-10. }\end{array}$ & $\begin{array}{l}\text { Prohibits unauthorized activity on specified public or private land that could } \\
\text { harm a nest or den of certain listed wildlife. Migratory birds identified under } \\
\text { federal law are identified in this legislation. }\end{array}$ \\
\hline
\end{tabular}

\section{PROVINCIAL LAWS}

\section{a. Water Act}

In the Water Act, "water” means "all water on or under the surface of the ground, whether in liquid or solid state." 95 The "property in and the right to the diversion and use of all water" in Alberta is vested in the provincial Crown. ${ }^{96}$ Diversion and use of water, including water in wetlands, is controlled under the provisions of the Water Act. ${ }^{97}$ AENV administers the Water Act and approves the disturbance of water and the beds and shores of water bodies, such as wetlands. ${ }^{98}$

Unless exempt under the regulations, "maintaining, removing or disturbing ground, vegetation or other material ... in or on any land, water or water body,"99 including draining and filling, is an "activity" that requires prior approval under the provisions of the Water

$95 \quad$ Water Act, supra note 8, s. 1(fff).

96 Ibid., s. 3. Exceptions to the general provisions are listed in the regulations. See Water (Ministerial) Regulation, Alta. Reg. 205/1998, Sch. 1. A notable exemption from licensing is diversion of water for household use under the Water Act, s. 21.

$97 \quad$ Water Act, ibid., s. 3.

$98 \quad$ Ibid., ss. 36-37 (these sections provide for approvals and application requirements).

$99 \quad$ Ibid., s. 1(1)(b). 
Act. ${ }^{100}$ This applies if a wetland is man-made or temporary and the bed and shore is considered private land by SRD, or if a wetland is permanent and naturally occurring and the bed and shore is claimable as public land. In either case, removal of water from a wetland requires prior authorization, unless exempt under the Water Act ${ }^{101}$ or the Water (Ministerial) Regulation. ${ }^{102}$

The Director also administers provincial policies and procedures, such as those in the Guide, ${ }^{103}$ and approves compensation for loss of water and natural habitat in wetlands when disturbance is approved. The Director may consider municipal policies and bylaw provisions for protecting wetlands from the impacts of development when deciding whether to issue approvals to disturb water bodies being managed by municipalities. ${ }^{104}$

The Water Act provides for water management planning, taking an integrated approach to planning with respect to water, land, and other resources. ${ }^{105}$ One of the principles of an integrated approach is to plan on a "watershed basis," ${ }^{106}$ which essentially is integrated water and land use management. Municipalities may wish to enact water body management bylaws and adopt plans to manage water bodies within their boundaries consistent with the water management planning provisions in the Water Act. Municipal water body management bylaws and plans could provide guidance to municipal planners, operations staff, and the Director when making administrative decisions under the Water Act that may impact local water bodies.

The Minister of Environment may designate "flood risk areas" and control land use in those areas under s. 96 of the Water Act, if "there is or may be a risk to human life or property as a result of flooding." ${ }^{107}$ The Minister may specify any "acceptable land uses with respect to the flood risk area." ${ }^{108}$ Section 96(2) states:

If the Minister has made a designation under subsection (1)(a), subject to the regulations,

(a) new Government works or undertakings must not be located or carried out,

Ibid., s. 36. Drainage, siltation of water, and erosion of a bed and shore of a water body are all "activities." If development "causes, may cause or may become capable of causing an effect on the aquatic environment” a prior approval is required. There are exemptions: see Water (Ministerial) Regulation, supra note 96. Water Act, ibid., s. 21.

Water (Ministerial) Regulation, supra note 96. Schedule 1 includes exempt activities that do not require approvals. For example: boat docks adjacent to water bodies; fence maintenance in a water body; crossings - limited to a single span bridge under certain prescribed circumstances; some forms of landscaping; etc.

103 Guide, supra note 10.

104 Water Act, supra note 8, ss. 38(2)(c)(ii), 51(4)(c)(iii), where the Director may consider any matters in the opinion of the Director that are relevant when making decisions to issue approvals and licenses respectively.

105 Ibid., ss. 7-15.

106 Framework, supra note 8 at 6 ("Water must be managed using an integrated approach with other natural resources: The interdependence of water quality and quantity is recognized; the interdependence of natural resources is recognized and; water management is based on a watershed approach"). Water Act, supra note 8, s. 96(1). The designation under s. 96(1)(a) can be made in any area of the Province, and can be made generally or on an interim basis. The discretionary power to designate is subject to the regulations, however there are currently no regulations in place with regard to s. 96. Ibid., s. 96(1)(b). 
(b) Government financial assistance must not be given to any person who engages in a use other than a use specified under subsection 1(b), and

(c) money and services and Government disaster assistance programs may be restricted with respect to flood damage,

in the designated flood risk area after the designation has been made, except as specified in the designation or the regulations. 109

There are currently no regulations addressing s. 96. The Minister must consult with the municipality in which the lands will be designated before making a designation. ${ }^{110}$ It may be possible for the Minister to work with municipalities to designate lands adjacent to wetlands and overlying aquifers as flood risk areas and ensure that appropriate land use patterns are established for those areas.

\section{b. Public Lands Act}

This section discusses a number of Public Lands Act provisions relevant to the protection of wetlands and watersheds, including riparian lands. SRD implements provisions of the Public Lands Act on Alberta's public lands, including beds and shores of all natural watercourses and permanent and naturally occurring water bodies, and determines their disposition, use, and development.

Sometimes private landowners think their property rights extend into public lands and they build unauthorized structures, remove riparian or aquatic vegetation to create pathways and beaches, or fill wetlands to create more arable land for agriculture.

Section 47 of the Public Lands Act is a very powerful regulatory tool, prohibiting such "unauthorized use of public lands," such as beds and shores. ${ }^{111}$ Unless a person has a preexisting disposition or is otherwise authorized to do so under the Public Lands Act, a person who occupies public land is considered a trespasser and any improvements made by such person are the property of the Crown. The Minister of SRD may order unauthorized structures to be "removed, demolished, sold or otherwise disposed of." 112 Under s. 47.1, the Minister may issue an order to vacate the public land subject to terms and conditions, and under s. 48, may require that the trespasser pay for unauthorized use. The amount payable becomes a debt owed to the Crown.

Section 54 of the Public Lands Act is also relevant to the protection of wetlands and watersheds. This section prohibits: the accumulation of waste, debris, refuse, or garbage on public lands; structures or excavations that are "undesirable"; the existence of any condition that may cause danger by fire to life, property, or forest growth; and three other important prohibitions written out in toto below: 
54(1) No person shall cause, permit or suffer

(d) the doing of any act on public land that may injuriously affect watershed capacity.

(e) the disturbance of any public land in any manner that results or is likely to result in injury to the beds and shores of any river, stream, watercourse, lake or other body of water or land in the vicinity of that public land.

(f) the creation of any condition on public land which is likely to result in soil erosion. ${ }^{113}$

Many daily human activities in the White Zone affect watershed capacity, disturb the beds and shores of lakes, rivers, and wetlands, or result in soil erosion; for example, off-road vehicles damage beds and shores and riparian lands, and cause soil erosion.

The provisions above are limited to unauthorized activities and uses. If a person has a disposition or is authorized to engage in an activity, these prohibitions may not apply. SRD compliance officers enforce the prohibitions and may levy fines of up to \$5,000 for each day that an offence continues. Municipalities could be persons who "permit or suffer" these prohibited activities on beds and shores if they do not take any action to control or regulate such harmful activities on public lands within their boundaries.

Section 54.01 is relevant to wetland and watershed protection as well. It prohibits certain uses of "closed roads" on public lands. It is an offence to travel on or enter a closed road. Section 54.01(4) can curtail private operators who charge people to access a public beach on a lakeshore: "No person shall, directly or indirectly, induce or attempt to induce another person to provide money or other consideration for the purpose of gaining access to, passage on or over or use of public land” unless authorized or entitled to in accordance with a lease or disposition. ${ }^{114}$

In summary, there are a number of Public Lands Act provisions that municipalities could rely on to request that SRD enforce against those activities and uses that violate municipal wetland and riparian land protection and management objectives in, on, or near beds and shores of water bodies and associated riparian lands located within municipal boundaries.

\section{c. Referral of Municipal Subdivision Applications to SRD}

The Subdivision and Development Regulation requires circulation of municipal subdivision applications to SRD when lands subject to subdivision application are "adjacent" to the beds and shores of water bodies to ensure that subdivisions and development of private lands do not adversely affect water bodies. ${ }^{115}$ Nevertheless, recently, SRD determined that

Ibid., s. 54 [emphasis added].

Ibid., s. 54.01(4).

Alta. Reg. 43/2002 , s. 5(5)(e):

On receipt of a complete application for subdivision, the subdivision authority must send a copy to the Deputy Minister of the Minister responsible for administration of the Public Lands Act if the proposed parcel (i) is adjacent to the bed and shore of a river, stream, watercourse, lake or other 
it would no longer review individual circulations of proposed subdivisions. Instead, SRD will now only conduct a "review of statutory and non-statutory higher-level municipal planning proposals at the initial stages in the planning cycle." $" 16$ These procedures came into effect on 1 October 2007 and are important to municipal planning and development because they change the usual subdivision and development application circulation process, and provide guidelines to help municipalities establish wider environmental reserve strips adjacent to water bodies than the minimum six-metre strip described in s. 664 of the MGA. The following was taken from the SRD on-line information services:

[SRD] shares common interests with municipalities related to land and resource management and planning and how this may be affected by land use zoning and the subdivision and development of land. Due to the large volume of municipal planning referrals received from across the province, the department is no longer able to provide a detailed review for each referral received involving a proposed subdivision.

The department understands that, as a municipality, you are obligated to send our offices a copy of a proposed subdivision that may affect a provincial water body. To ensure that municipalities continue receiving high-quality service, [SRD] will be shifting its focus from the review of individual applications for proposed subdivisions, to the review of statutory and non-statutory higher-level municipal planning proposals at the initial stages in the planning cycle. Provincial interests will be identified at that time. Similarly, the department will be providing recommendations for Environmental Reserve dedications through a new guideline that will be applicable to all proposed subdivision referrals. It is anticipated that this will streamline our referral review processes, provide more timely responses to municipalities and enable more effective and integrated land use planning.

Effective October 1, 2007, the department will prioritize responses to municipal planning referrals according to the following:

\section{Referrals Involving High Level Municipal Plans}

- $\quad$ Higher level planning initiatives (e.g., Area Structure Plans, Municipal Development Plans, Concept Plans, Outline Plans).

- $\quad$ Plans and initiatives identified as priorities by municipalities.

- Multi-lot subdivision proposals that affect areas of high environmental significance or public interest (e.g., particularly those related to recreational lakes or significant permanent and naturally occurring slough/marsh wetlands; or rivers and streams that are directly bounded by or flow through the proposed area).

Please be advised that $[S R D]$ will not be responding to referrals that do not fall within the general categories listed above.

body of water; or (ii) contains, either wholly or partially, the bed and shore of a river, stream, watercourse, lake or other body of water.

"Adjacent” is defined for the purpose of this clause, and “means contiguous or would be contiguous if not for a railway, road or utility right of way or reserve land (see s. 5(2)).

116 Alberta Sustainable Resource Development, "Municipal Planning Referrals,” online: Alberta Sustainable Resource Development <http://www.srd.gov.ab.ca/lands/usingpublicland/planning/ municipalplanningreferrals.aspx $>$. 


\section{Subdivision Referrals and Waterbodies}

Pursuant to Section 664 of the Municipal Government Act, a subdivision authority may require Environmental Reserves to be dedicated when a parcel is adjacent to a water body, subject to flooding or includes a swamp, gully, ravine, coulee or natural drainage course [emphasis added]. [SRD] will begin providing Environmental Reserve recommendations to municipalities in the form of the enclosed Guidelines for Recommended Minimum Reserve Widths Adjacent to Water Features whether or not a water body has been identified by the proponent.

The guidelines provide suggested minimum reserve widths to minimize impact to water bodies and maintain public access to Alberta's valuable public land resources. These guidelines summarize recommendations that [SRD] has previously provided to municipalities. It is recognized that some municipalities have demonstrated leadership by implementing policies that meet or exceed the minimum recommended widths. ${ }^{117}$

\section{The SRD's guidelines regarding recommended minimum reserve widths adjacent to water features ${ }^{118}$ include the following messages:}

SRD's goal is to have adequate riparian buffers established between a proposed development and a lake, river, watercourse, or wetland. SRD strongly supports the use of Environmental Reserve lands that support a reserve's protective functions. Activities such as clearing of vegetation, infilling, slope re-grading or excavation, drainage into or out of, discharge of effluents, or disposal of debris or other waste can impair those protective functions. SRD strongly supports municipalities in using all available tools and best management practices available to them to ensure that the long-term integrity and functionality of Environmental Reserve lands are maintained. These tools include, but are not limited to, by-laws and conditions on development permits that:

- reflect the sensitivity of the lands and which are likely to continue to preserve the functions that a healthy riparian area provides;

- ensure Environmental Reserves are not affected by grading of adjacent lots prior to construction and development arising out of the subdivision and development process. For example, the use of Grading Permits would provide a mechanism where erosion and sediment control measures can be directed to prevent pollution of aquatic environments;

- ensure the protection of tree cover in areas deemed to be environmentally sensitive, especially in areas adjoining water bodies and watercourses, or where lands are subject to erosion or slope failure; avoid, wherever possible, the enclosure of long stretches of a natural watercourse so that they continue to remain above ground. SRD encourages municipalities to utilize bridges at larger or more sensitive streams rather than culverts; and

- incorporate natural wetland areas into green space and park systems wherever possible with sufficient buffer areas to facilitate their long-term sustainability. ${ }^{119}$

Ibid. [emphasis in original].

Government of Alberta, Sustainable Resource Development Standard Recommendations to Municipal Subdivision Referrals (Includes Recommended Minimum Environmental Reserve Widths) (Edmonton: Alberta Sustainable Resource Development, 2007) at 2 [SRD Guidelines], online: Alberta Sustainable Resource Development <http://www.srd.gov.ab.ca/lands/usingpublicland/planning/pdf/SRD_ Municipal_\%20Subdivision_1.pdf >. Ibid. 
The guidelines recommend environmental reserve widths in excess of the "minimum 6 metre strip" adjacent to most water bodies to prevent pollution or provide access to beds and shores. ${ }^{120}$ They also make recommendations concerning requiring dedication of other features of the natural environment, such as ravines and steep slopes. These are important new tools to implement municipal wetland and associated riparian land protection policies at the time of subdivision of private parcels. SRD states that it wants to promote municipal initiatives to create scientifically justifiable building development setback policies that exceed the guidelines. ${ }^{121}$ The SRD web site further advises municipalities that

as administrators of the Public Lands Act, a non-response to a subdivision referral and water body is not equivalent to a waiver of the Crown's claim of ownership to the bed and shore of a water body. As per section 3 of the Public Lands Act, the title to beds and shores of all permanent and naturally occurring bodies of water and all naturally occurring rivers, streams, watercourses and lakes is vested in the Crown in right of Alberta. $^{122}$

\section{d. EPEA Generally}

The EPEA is particularly important for protecting wetlands and associated riparian lands from the impacts of development, as the legislation and regulations apply to most municipal operations including potable water supply, water treatment and distribution, waste water treatment, storm water management, pesticide applications, waste management, etc. ${ }^{123}$ In most cases, approvals are required pursuant to the EPEA regulations for buildings or development within municipal boundaries, and for essential public utilities, such as water treatment and distribution infrastructure, or private water wells and septic systems. Also, EPEA approvals are required before naturally occurring wetlands can be reconfigured as storm water catchments basins, or included as infrastructure in site-specific storm water management plans for private lands proposed for subdivision. ${ }^{124}$

\section{e. EPEA Storm Water Management Systems and Plans}

Storm water management plans and systems are considered during municipal land use planning and development processes. Municipal storm water management systems are approved and controlled by AENV under EPEA provisions and regulations. ${ }^{125}$ Municipal storm water management must be done in accordance with provincial policies, laws, regulations, codes of practice, and guidelines. Generally, a municipality is required to develop a "Master Drainage Plan" to manage the infrastructure and natural features in the municipality's storm water management system. ${ }^{126}$ At the subdivision or development level, the municipality will require that a developer provide a complementary site-specific storm water management plan to meet the objectives of the municipality’s Master Drainage Plan.

Ibid. at 3.

Ibid. at 2.

Alberta Sustainable Resource Development, supra note 116.

EPEA, supra note 22.

Ibid. Also see Wastewater and Storm Drainage Regulation, Alta. Reg.119/93. See Government of Alberta, Stormwater Management Guidelines for the Province of Alberta (Edmonton: Alberta Environmental Protection, 1999).

Wastewater and Storm Drainage Regulation, ibid.; Wastewater and Storm Drainage (Ministerial) Regulation, Alta. Reg. 120/93.

Wastewater and Storm Drainage Regulation, ibid., ss. 3-4. 
Controlled storm water volume and rate of flow can be achieved through implementation of "low impact development" technologies and strategies, such as pervious surfacing materials and naturescaping, which allow a maximum amount of storm water to be retained on-site on a lot by lot basis. Provincial guidelines and best management practices are evaluated by each community to determine which practices will work best based on local geology, soils, vegetation, topographic features, etc. For example, traditional methodology may not work if adjacent lands are steep with a ravine system that provides the historic drainage system for extensive acres of upland terrain.

As a condition of subdivision or development, a municipality may require that a developer use clay lined storm ponds and constructed wet facilities for storm water retention or pretreatment, in accordance with an existing municipal storm water policy or plan, such as a Master Drainage Plan. As an example of a best management practice, storm water interceptors or similar technology could be required in all industrial developments to pretreat contaminated storm water before release into storm water management systems and, ultimately, through sensitive riparian lands into streams, rivers, lakes, and wetlands. ${ }^{127}$

\section{f. EPEA Conservation Easements}

In order to protect or enhance the environment, the Minister of Environment may enter into an agreement with a registered landowner to restrict the purposes for which the land may be used by the registered owner, and compensation may be payable by the government or the registered owner under the terms of the agreement:

(1) In order to protect and enhance the environment, the Minister may enter into an agreement with the registered owner of land to restrict the purposes for which that land may be used by the registered owner and the successors in title of the registered owner.

(2) An agreement under this section may provide for the payment of compensation by the Government or by the registered owner of the land. ${ }^{128}$

Sections 22-24 of EPEA provide for “conservation easements,” which enable registered landowners to enter into an agreement with a "qualified organization" for a number of conservation purposes as listed below:

A registered owner of land may by way of agreement grant to a qualified organization a conservation easement in respect of all or part of the land for one or more of the following purposes:

See Government of Alberta, Environmental Reference Manual for the Review of Subdivisions in Alberta (Edmonton: Alberta Environmental Protection, 1996).

EPEA, supra note 22, s. 21. See Judy Atkins, Ann Hillyer \& Arlene Kwasniak, Conservation Easements, Covenants and Servitude in Canada: A Legal Review (Ottawa: Environment Canada, 2004) [Atkins, "Conservation Easements"] for an overview of conservation easements in Alberta and throughout Canada. The ALSA, supra note 89, amends the EPEA. Conservation easement provisions are now enabled under the legislative regime of the $A L S A$, along with conservation directives and transfer of development credits, a discussion of which is the topic of a new paper. The requirement for regional planning and mandatory consistency with regional plans are also part of the $A L S A$, however, to date no regional plans have been developed thereunder. 
(a) the protection, conservation and enhancement of the environment, including, without limitation, the protection, conservation and enhancement of biological diversity;

(b) the protection, conservation and enhancement of natural scenic or aesthetic values;

(c) providing for any or all of the following uses of the land that are consistent with purposes set out in clause (a) or (b):

recreational use;

open space use;

environmental education use;

(iv) use for research and scientific studies of natural ecosystems. ${ }^{129}$

The EPEA defines who is considered a "qualified organization,” and this includes the Government of Alberta, a government agency, a local authority (which includes a municipality), or a body corporate, such as Ducks Unlimited, if it meets prescribed EPEA qualification criteria. ${ }^{130}$ For the purpose of s. 22, "biological diversity" means the "variability among living organisms and the ecological complexes of which they are a part, and includes diversity within and between species and ecosystems."131 Wetlands and associated riparian lands might be considered "ecological complexes" necessary for sustaining biological diversity because certain species of plants require fluctuating water levels throughout the growing season, and certain species of waterfowl require these environments for breeding and nesting in the early spring.

A conservation agreement enables the private landowner to retain title to the property while relinquishing certain ownership rights, such as the right to develop riparian land, in order to protect or preserve the landscape's natural character. With a conservation easement registered on title, the landowner and future landowners are bound to not make changes to the lands protected by the easement that would violate easement terms. Such terms could include prohibiting development in riparian lands or filling in wetlands.

EPEA, ibid., s. 22(2) [emphasis added].

Ibid., s. 22(1)(e). To be a qualified organization for the purposes of conservation easements, a body corporate must have "as one of its objects the acquisition and holding of interests in land for purposes that are substantially the same as any of the purposes" of conservation easements; must have "in its consisting instrument a requirement that, on or in contemplation of the winding-up of the body corporate, all conservation easements that the body corporate holds are to be transferred to another qualified organization"; and it must be a registered charity within the meaning of the Income Tax Act, R.S.C. 1985 (5th Supp.), c. 1 (s. 22(1)(e)(iv)(A), (B), (C)).

EPEA, ibid., s. 22(1)(a). 
g. Surveys $\mathrm{Act}^{132}$

The extent of the bed and shore of a permanent and naturally occurring wetland and the legal "bank" are determined by an Alberta Certified Legal Surveyor under the provisions of the Surveys Act. ${ }^{133}$

In a recent article, Arlene Kwasniak clarified how to establish Crown ownership of the beds and shores of wetlands under the Public Lands Act:

To establish Crown ownership under the Public Lands Act, a [water] body must have a bed and shore, must be naturally occurring, and permanent. The bed and shore requirement is first and foremost. In accordance with the Surveys Act, unless the land underlying and on the sides of a water body have been "...covered so long by water as to wrest it from vegetation or as to mark a distinct character on the vegetation where it extends into the water or on the soil itself" the body is not Crown owned. ${ }^{134}$

Kwasniak argues that a wetland may be Crown owned if it is naturally occurring whether or not there is always water present, provided that there is an established bed and shore. ${ }^{135}$ Unfortunately, since 1984, SRD has taken the position that the beds and shores of wetlands located on private lands that contain water less than seven months of the year are not "claimable" by the Province. Both SRD and AENV take the position that once water is drained from such a wetland, the bed and shore belong to the landowner of the surrounding property. ${ }^{136}$ SRD and AENV's position causes problems for municipalities and landowners who can never be sure who owns the bed and shore of a wetland until a survey is completed, usually during the subdivision process.

\section{R.S.A. 2000, c. S-26.}

Ibid. The legal bank is determined by an Alberta Certified Legal Surveyor. These specialists may not be experts in hydrogeology or be adequately trained to determine the extent of the aquatic environment. The terms "bank" and "bed and shore" are defined and described in s. 17 of the Act dealing with determining natural boundaries, as follows [emphasis added]:

(1) A surveyor who needs to determine the position of a natural boundary when performing a survey under this Act may do so by any survey method that has the effect of accurately determining its location at the time of survey, relative to the surveyed boundaries of the affected parcel.

(2) When surveying a natural boundary that is a body of water, the surveyor shall determine the position of the line where the bed and shore of the body of water cease and the line is to be referred to as the bank of the body of water.

(3) For the purposes of this section, the bed and shore of a body of water shall be the land covered so long by water as to wrest it from vegetation or as to mark a distinct character on the vegetation where it extends into the water or on the soil itself.

Body of water is not defined in the Act.

Kwasniak, “Alberta Crown Ownership,” supra note 4 at 85 [footnote omitted].

Ibid. at 85.

See supra note 16. In conversations and e-mail exchanges with Haekel of SRD in January-November, 2007, he stated that the beds and shores of temporary wetlands (those that contain water for less than seven months of the year (see supra note 30) are not claimable by the Province under the Public Lands Act. Haekel indicated that the beds and shores of temporary wetlands are considered private lands by the Province. Where water is present in a wetland on an intermittent or seasonal basis for less than seven months of the year, certain soil and vegetation characteristics are present. Also see Interim Wetland Policy, supra note 1 for description. I argue that if the beds and shores of temporary wetlands are private lands, once the Province approves the removal of the water, municipalities are responsible to prohibit or regulate and control the use and development of the beds and shores of temporary wetlands within municipal boundaries. I argue that provincial approval to remove the water does not enable the approval holder to fill in the drained, privately owned beds and shores without a municipal development permit. 
Ownership of the bed and shore is important because if the bed and shore are private lands, the municipality has to determine the appropriate land use and regulate and control development. If the bed and shore of a wetland is claimed by the Province, then SRD authorizes land use, lease of occupation, or disposition. As discussed earlier, AENV approves activities that disturb the water in a wetland, such as draining water and infill, and arranges for compensation.

\section{h. Other Provincial Legislation}

Other provincial laws and regulations may affect municipal bylaws to control human activities and development of wetlands and associated riparian lands within municipal boundaries, such as the Land Titles Act, ${ }^{137}$ the Safety Codes Act, ${ }^{138}$ and the Building Code Regulation. ${ }^{139}$ I do not discuss these enactments further.

\section{PROVINCIAL POLICIES}

Three noteworthy provincial policies that could help municipalities to frame municipal bylaws and plans to manage wetlands and associated riparian lands are: the Wetland Management Plan in the Settled Area of Alberta: An Interim Policy ${ }^{140}$ and the Guide; Water For Life: Alberta's Strategy for Sustainability ${ }^{141}$; and the Land Use Policies. ${ }^{142}$

\section{a. The Interim Wetland Policy and the Guide}

As discussed above, provincial authorities are responsible, for the most part, ${ }^{143}$ for use of water in wetlands and development of beds and shores. In 1993, the Alberta Water Resources Commission recognized an ongoing loss of wetlands in the White Zone due to rapid growth in all sectors and, on their recommendation, the Province adopted the Interim Wetland Policy. The goal of the policy was as follows:

[T] he Government of Alberta is to sustain the social, economic and environmental benefits that functioning wetlands provide, now and in the future.

The intent of the policy is further defined as follows, in descending order of preference: a) to conserve slough/marsh wetlands in a natural state. b) to mitigate degradation or loss of slough/marsh wetland benefits as near to the site of disturbance as possible. c) to enhance, restore or create slough/marsh wetlands in areas where wetlands have been depleted or degraded. ${ }^{144}$

Supra note 85.

R.S.A. 2000, c. S-1.

Alta. Reg. 117/2007.

Interim Wetland Policy, supra note 1.

Water for Life, supra note 7.

Land Use Policies, supra note 93.

See supra note 16.

Interim Wetland Policy, supra note 1 at 1, 3 [emphasis in original]. See "Wetlands," online: Alberta Sustainable Resource Development <http://www.srd.gov.ab.ca/lands/usingpublicland/shorelands/wet lands.aspx\#awp>. 
Most wetlands found in the White Zone are referred to as slough/marsh wetlands ${ }^{145}$ or prairie potholes. ${ }^{146}$ Slough/marsh wetlands are described as

shallow, depressional areas that are permanently or periodically covered by standing or slowly moving water. Water levels often fluctuate and open water may or may not be present. Vegetation may range from floating or submerged plants in the centre to cattails, rushes, sedges and grasses to willows and other shrubs along the fringes or margins. Potholes and marshes along watercourses fall into this category. Slough/marsh wetlands are most common in central or southern Alberta. ${ }^{147}$

Notwithstanding the Interim Wetland Policy's clear provincial policy directing municipalities to conserve slough/marsh wetlands in the White Zone in situ, in 2008 sloughs and marshes continued to be drained and filled to accommodate human activities and development. Where sloughs and marshes are preserved, they are severely impacted by development activities, sometimes even purposefully deepened and reconfigured to be used as storm water retention ponds. ${ }^{148}$ Perhaps that is because AENV only released the Guide in 2005 with provincial interpretation of the Interim Wetland Policy's direction "to enhance, restore or create slough/marsh wetlands." 149

The Guide was revised in 2007 to provide better guidance to municipalities and the Director under the Water Act for wetland restoration/compensation, and reiterates the Interim Wetland Policy options, in descending order of preference, when a proposed development could impact a slough or marsh: (a) avoid impacts; (b) mitigate impacts that cannot be avoided; and (c) if it is impossible to avoid or mitigate impacts, compensate for loss of the water and natural habitat. Compensation is used to restore degraded wetlands elsewhere in the region or the Province.

“Avoid," "mitigate,” and “compensate” are the same terms used in the Land Use Policies, discussed below. The compensation process recommended in the Guide applies to proposed development in all naturally occurring wetlands whether water is present on a temporary or permanent basis. The Interim Wetland Policy provides background information and methodology to help municipalities systematically identify, classify, and map wetlands in accordance with the Land Use Policies. The Interim Wetland Policy and Guide are useful tools that could be used by municipalities in the White Zone to frame local wetland policies,

Interim Wetland Policy, ibid. at 3.

See Northern Prairie Wildlife Research Center, "Wetlands in the Prairie Pothole Region: Invertebrate Species Composition, Ecology and Management," in U.S. Geological Survey at 1, online: The Northern Prairie Wildlife Research Center <http://www.npwrc.usgs.gov/resource/wetlands/pothole/prairie.htm>. Interim Wetland Policy, supra note 1 at 1, 3. See Darren B. Sjogren et al., "Incipient tunnel channels" (2002) 90 Quaternary International 41 at 41-56 for an alternative theory to how the beds and shores of slough/marsh wetlands were created as "erosional landforms cut into glacial sediments.” This theory refutes that "hummocky terrain” resulted from "tunnel channels or subaerial tunnels partly filled with sediment from a subsequent glacial advance, a stagnating ice roof, or slumped sediment from the channel margins."

See Aquality Environmental Consulting Ltd. et al., Strathmore's Wetlands Discussion Paper (Strathmore: Town of Strathmore, 2006) at 9-12. Also see City of Red Deer, East Hill Major Area Structure Plan (Parkland Community Planning Services: The City of Red Deer, 2005), s. 5.1: "The City will also support alternative methods of storm water management, including the creation of permanent man-made storm water ponds and the incorporation of natural marshes or wetlands into the overall storm water system (i.e. green infrastructure), where this can be accomplished without causing concerns for potential flooding."

Interim Wetland Policy, supra note 1 at 3. 
goals, and strategies to protect wetlands from the impacts of human activities and development. Municipalities could then implement wetland conservation policies through municipal bylaws and land use bylaw regulations.

Few Alberta councils have adopted "wetland plans" or "wetland policies" to provide direction to municipal administrators about expectations for protecting wetlands within their boundaries. An exception is the City of Calgary. In 2004, the City of Calgary adopted the Calgary Wetland Conservation Plan. ${ }^{150}$ Calgary was one of the first municipalities in Canada to have a wetland policy and since then other Alberta municipalities have followed suit. ${ }^{151}$ Municipal policies and plans provide direction for local implementation of provincial and local policies, plans, and best management practices, such as the use of the Guide. Wetland policies and plans may be incorporated into and implemented through municipal bylaws and land use bylaw regulations.

\section{b. Water For Life}

Water For Life is the Government of Alberta's strategy for sustainability. Although the policy document was drafted and promoted by AENV, it may affect the administration of provincial legislation by several, if not all, provincial government departments. Water For Life reflects that maintaining and protecting Alberta's water resources and the aquatic environment is in the "public interest." 152 One of the three goals of Water For Life is “[h]ealthy aquatic ecosystems,” which includes healthy wetlands and riparian lands. ${ }^{153}$

The AWC was established under Water For Life to work with regional watershed planning and advisory councils (WPACs), such as the Bow River Basin Council and the North Saskatchewan Watershed Alliance, and local watershed stewardship groups (WSGs). ${ }^{154}$ Through WPACs, municipalities partner with other municipalities, stakeholders, industry, and other levels of government to develop watershed management plans for water bodies and watercourses located within their jurisdictional boundaries. Watershed management plans created in accordance with Water For Life are essentially regional land use plans to manage impacts on regional water supply and water quality. Water For Life recognizes municipal councils and regional partnerships, such as the Calgary Regional Partnership, as integral partners in watershed management.

Supra note 4.

Town of Strathmore Wetland Conservation Policy (Strathmore: Town of Strathmore, 2006), online: Town of Strathmore <http://www.strathmore.ca/news.php?viewStory=229>; and Town of Cochrane, Policy 1502-01: Inventory of Wetlands, their Associated Riparian Lands, and the Development of a Wetland Protection Plan (Cochrane: Town of Cochrane, September 2006), online: Town of Cochrane <http://www.cochrane.ca/municipal/cochrane/cochrane-website.nsf/AIIDoc/95B966FOCF8D 96658725729SD0061C760/\$File/WetlandsPolicy.pdf $>$. I am currently drafting Rocky View’s Wetland Conservation and Management Policy and Implementation Plan in association with Westhoff Engineering Resources, Ltd.

See MGA, supra note 9, s. 617.

See Water For Life, supra note 7 at 7. The three goals of Water For Life are:

- "Safe secure drinking water supply"

- "Healthy aquatic ecosystems"

- "Reliable, quality water supplies for a sustainable economy." Ibid. at $14-17$. 
The term "watershed" does not appear in the Water Act, which regulates and controls the diversion and use of water. Watershed does not appear in the MGA, which regulates the use and development of most private lands in Alberta. However, in s. 6.3 of the Land Use Policies, discussed below, municipalities are encouraged to mitigate impacts on local water bodies as well as the "entire watershed" during subdivision and development activities on private and municipal lands.

In the Green Zone, the Public Lands Act requires SRD to consider an activity's impact on "watershed capacity" when implementing land use management plans under provisions of the Public Lands Act. ${ }^{155}$ SRD oversees creation and implementation of resource management plans and activities for commercial operations on public lands, such as detailed forest management plans and timber harvesting operations that may impact entire watersheds. To complement SRD's plans in the Green Zone, municipalities could create water body management plans to manage the use and development of water bodies within their boundaries in the White Zone. Such municipal water body management plans could become part of regional watershed plans, or be approved under the Water Act as water management plans for certain watersheds contained partly or wholly within municipal boundaries (for example, a permanent and naturally occurring wetland like Cochrane Lake located within the Municipal District of Rocky View).

\section{c. Land Use Policies}

The Land Use Policies ${ }^{156}$ were adopted by Ministerial Order in 1996 (Minister of Municipal Affairs) to provide overarching provincial policy direction and guidance to municipalities for land use planning and regulation where municipal interests might overlap or impact matters of provincial interest. That was three years after the Interim Wetland Policy was adopted to protect slough/marshes in the White Zone, so it is not surprising that wetland conservation is specifically addressed in the Land Use Policies. ${ }^{157}$

Among other planning considerations, the Land Use Policies provide goals and strategies for mitigating impacts of subdivision and development on identified features in the natural environment and water resources. To summarize those goals and strategies, a municipality, in consultation with AENV is encouraged to:

- $\quad$ identify significant features in the natural environment and significant water resources within municipal boundaries;

- $\quad$ determine appropriate land use patterns in the vicinity of identified features and water resources; and

- incorporate measures to minimize or mitigate any negative impacts on those features or water resources during subdivision and development. ${ }^{158}$

Public Lands Act, supra note 17, s. 54.

Land Use Policies, supra note 93 were established by the Lieutenant Governor in Council pursuant to the MGA, supra note 9, s. 622 on 6 November 1996, two years after the MGA was enacted.

Land Use Policies, ibid., ss. 5, 6.3.

Ibid. 
The Land Use Policies list the features of the natural environment that are to be identified and protected from the impacts of development:

- "significant ravines, valleys, stream corridors, lakeshores, wetlands and any other unique landscape area”;

- " areas which are prone to flooding, erosion, landslides, subsidence, or wildfire"; and

- “areas of significant fish, wildlife and plant habitat."159

These features are all riparian lands. Wetlands are included as important features in the natural environment and they are also listed as important "water resources" to be identified and protected from the impacts of subdivision and development.

The Land Use Policies provide a systematic approach to policy implementation for achieving the goal in s. 6.3, "Water Resources," of contributing "to the protection and sustainable utilization of Alberta's water resources, including lakes, rivers, and streams, their beds and shores, wetlands, groundwater, reservoirs, and canals"160:

Policies

1. Municipalities are encouraged to identify, in consultation with Alberta Environmental Protection, significant water resources within their boundaries.

2. Municipalities are encouraged to determine appropriate land use patterns in the vicinity of the resources identified in accordance with policy \#1, having regard to impacts on an entire watershed as well as local impacts.

3. If subdivision and development is to be approved in the vicinity of the resources identified in accordance with policy \#1, municipalities are encouraged to, within the scope of their jurisdiction, incorporate measures which minimize or mitigate any negative impacts on water quality, flow and supply deterioration, soil erosion, and ground water quality and availability. Municipalities are also encouraged to facilitate public access and enjoyment of these water features, and to protect sensitive fisheries habitat and other aquatic resources. ${ }^{161}$

The term "watershed" is specifically used in policy \#2 above, where "municipalities are encouraged to determine appropriate land use patterns in the vicinity of the [water resource] identified in accordance with policy \#1, having regard to impacts on an entire watershed as well as local impacts." Municipalities are also encouraged to "facilitate public access and enjoyment of these water features," which includes "significant" wetlands. "Significant" is not defined, but according to policy \#1, above, significant wetlands within municipal boundaries are to be identified and inventoried by the municipality in consultation with 
AENV. ${ }^{162}$ If subdivision or development is approved in the vicinity of identified significant wetlands, municipalities are encouraged "to protect sensitive fisheries habitat and other aquatic resources." 163 "Aquatic resources” are not defined. However, the Water Act defines “aquatic environment” as

the components of the earth related to, living in or located in or on water or the beds or shores of a water body, including but not limited to all organic and inorganic matter, and living organisms and their habitat, including fish habitat,

and their interacting natural systems. ${ }^{164}$

Development of private land impacts adjacent water resources and the aquatic environment because it causes: increased volumes and rates of flow of contaminated storm water runoff; increased installations of private septic systems; road development; compacted soils; and removal of trees and ground cover. These activities cause erosion, sedimentation, and contamination of local water bodies, and can have significant impacts on entire watersheds. ${ }^{165}$

The Land Use Policies provide a framework for municipalities to create municipal water body management policies and plans to achieve the goal of s. 6.3 and comply with policy \#3, above. Such a municipal water management plan could "incorporate measures which minimize or mitigate any negative impacts on water quality, flow and supply deterioration, soil erosion, and ground water quality and availability.” Through s. 6.3 of the Land Use Policies, the Province encourages municipalities to address such matters "within the scope of their jurisdiction" in response to subdivision and development activities under Part 17 of the MGA.

The Land Use Policies require "consistency" between the policies and municipal statutory plans, the land use bylaw, and actions taken under Part 17: "Each municipality is expected to incorporate the Land Use Policies into its planning documents and planning practices."166 The MGA states: "Every statutory plan, land use bylaw and action undertaken pursuant to [Part 17 of the MGA] by a municipality, municipal planning commission, subdivision authority, development authority or subdivision and development appeal board or the Municipal Government Board must be consistent with the land use policies.”167

Oxford English Reference Dictionary, 2d ed., s.v. "significant" means "1. having a meaning; indicative 2. having an unstated or secret meaning; suggestive... 3. noteworthy; important; consequential 4. Statistics of or relating to significance, departing from the null hypothesis." I submit that all wetlands are "significant" to the local ecology and removal or negative impacts on all wetlands can affect local water supply and water quality. 
It is unclear whether the Province assesses whether municipal statutory plans and land use bylaws are consistent with the Land Use Policies. The MGA does not grant a right for a person to appeal to a council or the Municipal Government Board to ensure that municipal plans, the land use bylaw, or decisions made by the development authority or council are consistent with the Land Use Policies as required in s. 622 of the MGA. Arguably, a person could apply to a court to determine "consistency" between the Land Use Policies and planning bylaws under Part 17 because the MGA requires "consistency.”

One of the major disadvantages to the Land Use Policies is that they are not specific enough. While they "encourage” certain municipal responses, they do not mandate municipal action beyond the requirement for "consistency" 168 and they focus on matters of public policy, not matters of law:

\footnotetext{
The Land Use Policies focus on matters of public policy, not matters of law. They provide a framework for statutory plans, land use bylaws, and planning decisions. The Land Use Policies should be interpreted as a guide to more specific municipal policy and action, and are not intended to be the basis of legal challenges. In applying the Land Use Policies municipalities must assess the importance of each policy in relation to the others in light of local and intermunicipal priorities. Municipalities must have regard to the cumulative effects of all of the policies as well as to the specific effect of each policy. ${ }^{169}$
}

The Land Use Policies, issued in 1996, provide that the policies are to be a "guide to more specific municipal policy and action" to protect identified local features of the natural environment and water resources from the impacts of development, specifically riparian lands and wetlands. ${ }^{170}$ However, the Province could issue new or revised land use policies that require compliance.

Municipal councils and planning department staff may not fully understand the value of the Land Use Policies. This is unfortunate because without any major legislative change, the current Land Use Policies provide municipalities with a policy framework and tools to develop statutory plans and land use bylaw regulations to protect wetlands and riparian lands within municipal boundaries in the White Zone from the impacts of subdivision and development.

\section{FEDERAL LAWS}

The most important federal laws that affect municipal bylaws for protecting wetlands and riparian lands from the impacts of human activities and development within municipal boundaries are: the Fisheries Act, the Migratory Birds Convention Act, ${ }^{171}$ the Navigable Waters Protection Act, ${ }^{172}$ and the Species at Risk Act. ${ }^{173}$

Ibid., s. 622; Land Use Policies, supra note 93, s. 3.

Land Use Policies, ibid. [emphasis added].

Ibid.

Supra note 92.

Supra note 69.

Supra note 92. Darcy M. Tkachuk, Alberta's Wetlands: Legal Incentives and Obstacles to Their Conservation (Calgary: University of Calgary, 1993). According to the authors, the Fisheries Act and the Migratory Birds Convention Act provide beneficial federal laws and regulations for protecting wetlands because wetlands may provide fish habitat or nesting habitat for migratory birds. The author states: 
These enactments protect navigability of waters, fish habitat, and nesting habitat for certain birds and species at risk that may be negatively impacted by human activities and development in wetlands and riparian lands. Within municipal boundaries, fish habitat may be found in wetlands associated with rivers, streams, and lakes, in which case the "no net loss” policy in the Fisheries Act would apply. ${ }^{174}$ Nesting habitat protected under Acts of Parliament may be found in riparian lands adjacent to wetlands, including slough/marsh wetlands not associated with rivers, streams, or lakes.

\section{FEDERAL Policies/Programs}

Three federal policies/programs that have a positive impact on wetland and associated riparian land conservation in Alberta's municipalities are the Canada Ecological Gifts Program, ${ }^{175}$ the National Environmental Farm Planning Initiative (NEFP), ${ }^{176}$ and the Federal Wetland Policy.

\section{a. The Canada Ecological Gifts Program}

The following is an explanation of the Canada Ecological Gifts Program, which encourages private landowners to protect lands containing wetlands and associated riparian lands that have been certified as "ecologically-sensitive” through "easements, covenants and servitudes” for certain tax incentives:

The Ecological Gifts Program (EGP) provides a way for Canadians with ecologically-sensitive land to protect natural areas and leave a legacy for future generations. Since 1995, donations of ecologicallysensitive land, or easements, covenants and servitudes on such land have been eligible for special tax assistance. Ecological gifts can be made to environmental charities approved by Environment Canada, as well as to any level of government in Canada. Under the EGP, Environment Canada certifies the land is ecologically sensitive, approves the recipient, and certifies the fair market value of the gift. In addition to the

At least two provisions of [the Fisheries Act] provide indirect prohibitions to the destruction of wetlands. Section 35(1) states that, unless ministerial authorization is obtained: No person shall carry on any work or undertaking that results in the harmful alteration, disruption, or destruction of fish habitat by any means.... In addition, s. 36(3) provides that, subject to regulation: no person shall deposit or permit the deposit of a deleterious substance of any type in water frequented by fish or in any place under any conditions where the deleterious substance or any other deleterious substance that results from the deposit of any deleterious substance may enter such water. The most evident obstacle to using the Fisheries Act for wetland conservation purposes is that sloughs, ponds, and marshes in Canada do not often support resident fish populations (at 13).

The authors also identify several federal laws that actually promote the destruction of wetlands in order to provide more arable acres for wheat production (at 10-11). Also, for a discussion on the Fisheries Act as "a broad legal framework for a watershed approach" to managing water resources throughout Canada, see Michael Moers Wenig, The Fisheries Act as a Legal Framework for Watershed Management (LL.M. Thesis, University of Calgary, Faculty of Law, 1999) [unpublished].

The Department of Fisheries and Oceans, Policy for the Management of Fish Habitat (Ottawa: Minister of Supply \& Services Canada, 1986) at 27 ("no net loss” means “[a] working principle by which the department strives to balance unavoidable habitat losses with habitat replacement on a project-by-project basis so that further reductions to Canada's fisheries resources due to habitat loss or damage may be prevented”).

Environment Canada, “The Ecological Gifts Program,” online: Environmental Canada <http://www. cws-scf.ec.gc.ca/egp-pde/default.asp?lang=En\&n=522AB5A3-1> [Ecological Gifts Program].

Agriculture and Agri-Food Canada, “National Environmental Farm Plan Initiative,” online: Agriculture and Agri-Food Canada <http://www4.agr.gc.ca/AAFC-AAC/display-afficher.do?id=1181579114202\& lang=eNGH $>$ [National Farm Plan Initiative]. See also Alberta Environmental Farm Plan Company, “Alberta Environmental Farm Plan Company,” online: Alberta Environmental Farm Plan Company <http://www.albertaefp.com/program/progWhy.html>. 
charitable donations tax credit (for individuals) and the charitable donations deduction (for corporations), donations made on or after May 2, 2006 and certified under the Ecological Gifts Program will no longer be subject to tax on any capital gains accruing in respect of the property. ${ }^{177}$

\section{b. The National Environmental Farm Planning Initiative}

The following describes the NEFP:

The Government of Canada's National Environmental Farm Planning Initiative helped Canada’s agricultural producers develop and implement environmental farm plans (EFPs) through provincially delivered EFP programs. Objectives of the National Environmental Farm Plan Initiative include:

- $\quad$ helping the agriculture sector better identify its impacts on the environment; and

- $\quad$ promoting the growth of stewardship activities within the agriculture industry.

- The National Environmental Farm Planning Initiative supports the environmental objectives of the federal-provincial-territorial Agricultural Policy Framework by:

- assuring Canadians that agricultural resources are being managed in a sustainable fashion; and

- helping to brand Canada in the global market as a source of safe, high-quality food produced in an environmentally responsible manner. ${ }^{178}$

The Alberta Environmental Farm Plan Company is a non-profit group that administers the Canada-Alberta Farm Stewardship Program created under NEFP. Through the program, eligible Alberta producers are provided with financial assistance to maintain or improve the quality of soil, water, air, or biodiversity resources on their lands. Alberta producers who complete Environmental Farm Plans and receive certificates under the program are eligible for financial support to implement "beneficial management practices" to "ensure the longterm health and sustainability of land-related resources used for agricultural production; positively impact the long-term economic and environmental viability of the agricultural industry; and minimize negative impacts and risk to the environment." ${ }^{179}$ The manual used by producers to prepare Environmental Farm Plans helps producers assess environmental risks associated with all aspects of their operations and provides advice and strategies to help producers minimize identified risks. Many of the environmental risks identified and resolved through the program relate to impacts of agricultural operations on water quality, especially storm water runoff issues. In-stream cattle watering, pesticide usage, and manure and fertilizer storage are examples of risks that are managed through the program. ${ }^{180}$

177 Ecological Gifts Program, supra note 175.

178 National Farm Plan Initiative, supra note 176

179 “Canada-Alberta Farm Stewardship Program,” online: Agriculture and Agri-Food Canada <http://www. 4.agr.gc.ca/AAFC-AAC/display-afficher.do?id=1181579114202\&lang=eng>.

180 Cindy Chiasson, “Agricultural Producers and Pollution Prevention: Alberta's Environmental Farm Plan” (Paper presented at the 12th Canadian Pollution Prevention Roundtable, Edmonton, Alberta, 12 June 2008). See also Government of Alberta, Beneficial Management Practices: Environmental Manual for Alberta Farmsteads (Edmonton: Alberta Agriculture, Food and Rural Development, 2006), online: Government of Alberta <http://www1.agric.gov.ab.ca/\$department/deptdocs.nsf/all/agdex11114>. 


\section{c. The Federal Wetland Policy}

The Federal Wetland Policy applies to all wetlands located on federal lands, or lands managed by the federal government, and provides important federal wetland conservation principles, policy objectives, and strategies that could be utilized by Alberta municipalities to frame local wetland conservation and management policies, plans, and bylaws.

\section{IMPORTING THE DEFINITION OF “WATER BODY” FROM THE WATER ACT}

At this juncture, before examining s. 60 further, it is important to note that "body of water" is not defined in the MGA. However, "water body" is broadly defined in the Water Act and means: "any location where water flows or is present, whether or not the flow or the presence of water is continuous, intermittent or occurs only during a flood, and includes but is not limited to wetlands and aquifers."181

The two provincial enactments use different words to describe the same subject matter, but the words can be interpreted using the principle of statutes in pari materia:

\footnotetext{
Statutes enacted by a legislature that deal with the same subject are presumed to be drafted with one another in mind, so as to offer a coherent and consistent treatment of the subject. The governing principle was stated by Lord Mansfield in R. v. Loxdale:
}

Where there are different statutes in pari materia though made at different times, or even expired, and not referring to each other, they shall be taken and construed together, as one system, and as explanatory of each other.

In effect, the several statutes are construed together as if they constituted a single Act and the presumptions of coherence and consistent expression apply to these statutes as if they were part of a single Act. ${ }^{182}$

Therefore, municipalities may apply the broad definition of "water bodies" from the Water Act to manage "bodies of water," which include wetlands and aquifers by definition. ${ }^{183}$ The "locations" of water bodies are then permanent landscape features where water flow is “continuous, intermittent, or occurs only during a flood." "184

Water Act, supra note 8, s. 1(1)(ggg) [emphasis added]. The definition does not reference "beds and shores.” The definition can also be used to interpret s. 3 of the Public Lands Act, supra note 17.

Ruth Sullivan, Driedger On The Construction of Statutes, 3d ed., (Vancouver: Butterworths, 1994) at 285. See also Ruth Sullivan, Sullivan and Driedger on the Construction of Statutes, 4th ed., (Toronto: Butterworths, 2002) at 324-30 regarding application of the principle of statutes in pari materia to interpretation of legislative provisions. See also Gahr v. Alberta, 1998 ABQB 938, 233 A.R. 168 at para. 19 where Johnstone J. cited Friends of Oldman River Society v. Canada (Minister of Transport), [1992] 1 S.C.R. 3, for the principle that "different statutes should be interpreted so far as possible, in a way that enables them to stand together."

The definition of "watercourse" in the EPEA, supra note 22, s.1(yyy) [emphasis added], is also important. It means: “(i) the beds and shore of a river, stream, lake, creek, lagoon, swamp, marsh or other natural body of water, (ii) or a canal, ditch, reservoir or other artificial surface feature made by humans whether it contains or conveys water continuously or intermittently.” See Strathcona County, By-law No. 8-2001, Land Use Bylaw (10 July 2001), s. 2.3. Water Act, supra note 8, s. 1(1)(ggg). 


\section{E. WHAT ARE THE LIMITATIONS ON SECTION 60?}

Section 60 falls within Part 3: "Special Municipal Powers and Limits on Municipal Powers," and is one of the Division 6: "Miscellaneous Powers" that authorize municipal action with respect to provincial interests and other matters.

The special municipal power granted in s. 60 seems to be limited only in that it is subject to any other enactment. (The limits to municipal powers provided in ss. 70-75 of the MGA do not pertain to water bodies, or to water body management under s. 60.)

As the MGA does not specify that the authority to "direct, control and manage" local water bodies granted in s. 60 is to be exercised by bylaw, a municipality could choose to exercise the authority through either a bylaw or a council resolution. ${ }^{185}$ A municipal council could enact a local water body management bylaw, or resolve to adopt a water body management plan, or could do both.

If a council adopts a s. 60 water body management plan by resolution, the water body management plan would be a policy document. As a policy document, it would direct municipal administrative procedures and operations with respect to human activities on, in, or near local water bodies. The policy could be adopted to apply to both private and municipal lands. If implemented through Part 17 "planning bylaws," such a policy could be used to manage land use and development activities on, in, or near wetlands and associated riparian lands. The goals and objectives, strategies, and best management practices in a water body management plan could also be implemented through a bylaw enacted under the authority granted in s. 60, or through Part 2, s. 7 bylaws. Regulations in a water body management bylaw could control human activities on, in, or near water bodies as long as those regulations are consistent with any other enactment.

\section{INTERPRETING “DiRECTION, CONTROL AND MANAGEMENT”}

\section{A. BACKGROUND}

In this section, I examine the special municipal power granted in s. 60. First, I begin with the legislative history of the phrase "direction, control and management" in Alberta municipal ordinances. Second, I argue that all naturally occurring wetlands are "bodies of water" for the purpose of s. 60. Third, I provide a brief analysis of a recent Alberta Court of Appeal decision where the phrase "direction, control and management" was judicially considered in relation to roads. Finally, I provide my conclusions regarding municipal water body management bylaws and plans. 


\title{
B. THE LEGislative History OF "Direction, CONTROL AND MANAGEMENT”
}

There are historic variations on the wording of the phrase "direction, control and management” in Alberta legislation. I provide a snapshot of Alberta ordinances and legislative provisions to illustrate how the language in s. 60 evolved since 1907. Some years ago, I drafted an abbreviated historic review of s. 60 for the Guidebook to Water Management ${ }^{186}$ and I reference portions of that review below.

The Ordinance respecting Municipalities of 1898 contains one of the earliest provisions granting Alberta municipalities jurisdiction over highways, bridges, and streams:

\begin{abstract}
Every Municipality shall have jurisdiction over all highways within the same and the Lieutenant Governor in Council may give a municipality jurisdiction over any highway, bridge or stream dividing municipalities or adjacent thereto when not dividing municipalities and may determine what portion of a highway, bridge or stream dividing municipalities shall be within the jurisdiction of each. ${ }^{187}$
\end{abstract}

By 1922, in the Town Act, the provision had been amended as follows:

338. All public roads, streets, bridges, highways, lanes, alleys, squares or other public places in a town shall be vested in and subject to the direction, management and control of the council for the public use of the town but always subject to the right of the Province to utilize the same for and in connection with any public work of the Province.

339. The Lieutenant Governor in Council may direct that any highway, bridge or stream not wholly within the town limits or any part of such highway, bridge or stream shall be subject to the direction, management and control of the council for the public use of the town. ${ }^{188}$

The phrase still exists in the Lloydminster Charter, where the Legislature provides that streams are to be managed for the "public use of the city":

The Lieutenant Governor in Council may by order direct that any highway, bridge or stream not wholly within the city, or any part of such highway, bridge or stream, shall be subject to the direction, management and control of the council for the public use of the city. ${ }^{189}$

The language of the phrase changed dramatically over the years, adding local water bodies to a list of "public works." In 1980, the old Municipal Government Act, under "Public Works," read as follows: "Subject to every other Act, a council has the control and management of the public highways, roads, streets, lanes, alleys, bridges, rivers, streams, watercourses, lakes, and other bodies of water within the municipality, including the air space above and the ground below." 190

Bow River Basin Council, Guidebook to Water Management (Calgary: Alberta Environment, 2002) at 143-49.

1898 C.O. N.W.T., c. 70, s. 85.

R.S.A. 1922, c. 108, ss. 338-39 [emphasis added].

Alta. Reg. 43/79, s. 108.

R.S.A. 1980, c. M-26, s. 172(3) [emphasis added]. 
The Province provided that water bodies, as defined today in the Water Act, located within municipal boundaries were "Public Works" in exactly the same way as highways and roads were public works. The adjective "public" preceded the entire list of those works, which included "other bodies of water.” Municipal “control and management” of water bodies was "subject to every other Act" in force at the time. Section 172(3) remained in place until the new MGA was enacted in 1994.

The old Municipal Government Act was reviewed between 1987 and 1992. A discussion guide was introduced in the Legislature in 1992 called 1992 Bill 51: Discussion Guide: A New Municipal Government Act for Albertans. ${ }^{191}$ The first attempt to separate local water bodies from roads and other public works was presented in the MGA Discussion Guide, under the Division heading: "Water Bodies, Air Space and Roads.” The provision was as follows: "Subject to any other enactment, a municipality has the direction, control and management of rivers, streams, watercourses, lakes and other bodies of water within the municipality, including the air space above and the ground below.”192

The MGA Discussion Guide articulated the changes to the special municipal power to manage water bodies:

- it was subject to "any other enactment” instead of “every other Act”;

- the special municipal power for “direction, control and management” of water bodies was separated from the special municipal power for "direction, control and management” of public highways, roads, etc.; and

- $\quad$ the word “direction” was added at the beginning of the phrase.

Between the time of the proposed "Water Bodies" provision in the 1992 MGA Discussion Guide and the enactment of s. 60 of the MGA in 1994, the only additional change made as a result of public consultation was the addition of the word "natural" before "bodies of water."193

\section{C. “NATURAL BODIES OF WATER” IN SECTION 60}

The property in the water in all water bodies is property of the Crown pursuant to s. 3 of the Water Act, and the title of the beds and shores of all permanent and naturally occurring bodies of water and all naturally occurring rivers, streams, watercourses, and lakes are vested in the Crown and are public lands under s. 3 of the Public Lands Act. I argue that all naturally occurring wetlands, whether they are permanent wetlands or the beds and shores, are claimed

Government of Alberta, 1992 Bill 51: Discussion Guide: A New Municipal Government Act for Albertans (Edmonton: Alberta Municipal Affairs, 1992) [MGA Discussion Guide].

192 Ibid., s. 127(1)

193 The Bow River Basin Council (BRBC) prepared a submission in response to the request for comments, which I drafted on behalf of the BRBC. I recall at the time that the addition of the word "natural" before water bodies was requested by the Irrigation Districts who wanted a clear distinction between natural water bodies and man-made infrastructure associated with irrigation works, especially canals and reservoirs. The BRBC member representing ranchers and cattle producers wanted the Legislature to differentiate between natural water bodies and agricultural dugouts. In any event, "natural” was inserted in the final draft of s. 60 . 
by the Crown as public lands and are "bodies of water" for the purpose of municipal management under s. 60 .

As discussed above, "water body" is defined in the Water Act and means: "any location where water flows or is present, whether or not the flow or the presence of water is continuous, intermittent or occurs only during a flood, and includes but is not limited to wetlands and aquifers." 194

By applying the principle of statutes in pari materia, as discussed earlier, the above definition can be used to define "bodies of water" in s. 60. Therefore, "natural bodies of water" in s. 60 includes all natural wetlands and aquifers.

In s. 60, the Province grants municipalities authority for the "direction, control and management" of "natural bodies of water" and does not indicate that the water bodies must be permanent. Section 60 does not limit "direction, control and management" to beds and shores underlying water bodies, but refers to "water bodies," which include the "locations" where water is present, including ephemeral, temporary, seasonal, and permanent wetlands. This is important because, under s. 60, municipalities may manage the locations where ephemeral wetlands occur naturally whether they have distinct beds and shores or whether water is found at that location year round. ${ }^{195}$

The Province uses similar language in Part 17 of the MGA to enable municipalities to require dedication of strips of riparian land adjacent to the beds and shores of all bodies of water as environmental reserves during the subdivision of private parcels of a certain size under certain conditions, whether the water bodies are natural, permanent, or man-made. It is important to note that these environmental reserve strips may only be required to be dedicated for two purposes: to prevent pollution and to provide public access to the adjacent water body. ${ }^{196}$

Also, in the provincial Land Use Policies, the Interim Wetland Policy, and the Guide, the Province encourages municipalities to avoid or mitigate impacts on significant natural resources and significant water resources, such as wetlands, during subdivision and development activities. None of the provincial policy documents discussed above restrict municipal authority for "direction, control and management” of wetlands to "permanent and naturally occurring water bodies.”

I argue that if the Legislature had wanted to limit the application of s. 60 to "permanent and naturally occurring bodies of water" as was done in s. 3 of the Public Lands Act, it could have easily done so. When the MGA was enacted in 1994, that was ten years after the Public Lands Act had been amended to ensure that the beds and shores of water bodies claimed under s. 3 of that Act were both "permanent and naturally occurring." Therefore, the

$194 \quad$ Water Act, supra note 8 at s. 1(1)(ggg) [emphasis added].

195 Section 60 also grants municipal authority to municipalities for the direction, control, and management of the air space above and the ground below water bodies, excepting out mines and minerals. The provision needs further examination concerning aquifers, and although it is important to understand the interconnection between surface and ground water from an integrated resource management perspective, I do not address aquifers further in this article. 
Legislature must have intended to ensure that municipalities had direction, control, and management of all natural wetlands, even if the presence of water within those water bodies was intermittent or occurred only in a flood.

\section{JUDICIAL INTERPRETATION OF "DIRECTION, CONTROL AND MANAGEMENT”}

Unfortunately, there is very little legal research or legal interpretation of the special municipal power granted to municipalities in s. $60 .{ }^{197}$ Municipal "direction, control and management" of local water bodies might mean something close to exercising "incidents of ownership," as described by Jeremy Waldron as "liberty of use, the right to exclude, and the various powers of transfer," ${ }^{\text {"198 }}$ subject to any other enactment, for example the Water Act, where the right to divert and use water from within a water body is already fully regulated.

The closest analogy of the relationship between the Province and municipal authority for the direction, control, and management of local natural water bodies might be to that of a landowner and a real estate property manager. The landowner never relinquishes ownership of the property in the real estate, but the property manager takes care of the property, regulates its daily use, excludes certain tenants, and arranges for leases and subleases. Both the property owner (the Province) and the property manager (municipality) have different rights and responsibilities concerning the management of the same property. If there is a question concerning real estate management policy, the landowner has the final say. If there is a legal matter with respect to the property, the landowner is responsible. The day-to-day and ongoing affairs of managing the property are left to the real estate property manager, who manages at the pleasure of the landowner. At any time, the landowner is able to revoke the property manager's mandate to manage the real estate. Similarly, the Legislature could always amend its laws and remove municipal authority for the direction, control, and management of local natural water bodies. It is worth noting that, in 1999, when the Water Act was enacted providing for "water management planning,", s. 60, but, instead strengthened municipal authority to partner in water management planning.

To interpret the scope of the special power granted to municipalities by s. 60, I start by comparing it to s. 18(1) of the MGA, which grants a similar special power to municipalities for "direction, control and management" of roads. Section 18(1) states as follows: "Subject to this or any other Act, a municipality has the direction, control and management of all roads within the municipality."200

The two provisions have some wording differences: s. 18(1) is a special power granted to municipalities "subject to the MGA and any other Act," while s. 60 is subject to "any other enactment." The different wording in the limitation on these special powers is important to the powers granted, and I suggest that this is subject matter for further research. There are

See Arlene J. Kwasniak, Alberta Wetlands: A Law and Policy Guide (Edmonton: Environmental Law Centre, 2001).

198 Jeremy Waldron, "Property Law" in Dennis Patterson, ed., A Companion to Philosophy of Law and Legal Theory (Cambridge, Mass: Blackwell, 1996) 3 at 8.

199 Water Act, supra note 8, ss. 6-13.

200 MGA, supra note 9 , s. 18(1). 
also provisions in the MGA that limit the special power for municipal management of roads, such as s. 22, which prescribes procedures for road closures. However, there are no other MGA provisions that specifically limit the special power in s. 60 .

I argue that unless an enactment exists that covers all aspects for regulating management of water bodies and also limits the special municipal power in s. 60, the power is broad. Given the Supreme Court of Canada decision in Spraytech ${ }^{201}$ supporting the principle of subsidiarity and the importance of local decision-making regarding environmental matters of a local nature, while a complete occupation of the regulatory field to manage local water bodies by either federal or provincial enactments is possible, such a regulatory regime may not exist or be desirable. Many aspects of managing local water bodies are already left to local governments, as discussed above.

There are similarities and differences between local roads and local water bodies. Historically, both have been considered "public works" and could be considered public goods. ${ }^{202}$ Roads are human constructs created for human purposes, such as public access and trade, while local water bodies are natural systems necessary to sustain all life. Roads are developed, maintained, and closed in certain locations. Local water bodies exist in nature in situ, although they are often "managed" for navigation, fisheries, recreational boating, swimming, water power, irrigation diversion, storage, flood attenuation, etc. through the Water Act, the EPEA, the Public Lands Act, and federal laws or statutory instruments.

The phrase “direction, control and management” was judicially considered in Belland with respect to roads. Justice Slatter for the Alberta Court of Appeal stated:

\begin{abstract}
Notwithstanding that ownership of the roads is in the Crown in right of Alberta, s.18 (1) of the M.G.A. then provides that the municipality has the "direction control and management of all roads within the municipality”, a concept carried forward in s.2 of the P.H.D. Act [Public Highways Development Act]. Interpreting this wording in the broad and purposive manner dictated by the Supreme Court, this section is intended to give municipalities wide-ranging authority over the roads within the municipality. The section appears to grant all rights with respect to roads short of an ability to alienate the title to the road, or the right to unilaterally close the road (see s.22). Section 2 of the P.H.D. Act makes the municipality responsible for construction and maintenance of highways. Section 532 of the M.G.A. goes on to provide that the municipality has a positive duty to keep the roads in a reasonable state of repair, and that the municipality is liable for any damages resulting from non-repair. ${ }^{203}$
\end{abstract}

A municipality is a "highway authority" under the Public Highways Development Act and can enforce provisions of that Act under s. 2: "Except as otherwise provided in an agreement made pursuant to this Act, each highway authority is responsible for the costs of construction and maintenance of all highways subject to its direction, control and management."204 of government that is not only effective, but also closest to the citizens affected and thus most responsive to their needs, to local distinctiveness, and to population diversity.”

202 Waldron, supra note 198 at 5-6.

203 Belland, supra note 35 at para. 18 [emphasis added]. 
Justice Slatter's interpretation of the special power granted by the phrase "direction, control and management," when applied to the s. 60 special municipal power to manage water bodies, seems to grant municipalities “wide-ranging authority over” water bodies, which includes wetlands and aquifers within the municipality. It seems to grant "all rights with respect to [water bodies] short of an ability to alienate the titles" to the beds and shores or the water within the water bodies, or the "right to unilaterally close" the water body to public access. It is true, however, that the MGA confers additional authority to municipalities for the management of roads, while no additional authority for the management of water bodies is found in the MGA, or for that matter the Water Act, the EPEA, or the Public Lands Act. But, provincial policies demonstrate provincial intent for municipalities to co-manage water resources and the Water Act does contemplate that the Minister of Environment could enter into agreements with municipalities for a number of specific water management projects as well as "any other matter related to the administration of this Act.",205

Section 532 of the MGA, referenced above by Slatter J.A., deals with municipal liability and responsibility for "repairs of roads, public places and public works."

Every road or other public place that is subject to the direction, control and management of the municipality, including all public works in, on or above the road or public place put there by the municipality or by any person with the permission of the municipality, must be kept in a reasonable state of repair by the municipality, having regard to

a. the character of the road, public place or public work, or

b. the area of the municipality in which it is located. ${ }^{206}$

Roads are clearly public works, and are defined in s. 1(1)(z) of the MGA as "land (i) shown as a road on a plan of survey that has been filed or registered in a land titles office, or (ii) used as a public road, and includes a bridge forming part of a public road and any structure incidental to a public road.”207 Municipalities manage roads, bridges, ditches, walkways, and other structures associated with roads located within their geographic boundaries with extensive policies, programs, and projects that are planned by the municipality and financed through general municipal revenues. The Public Highways Development Act and Traffic Safety Act ${ }^{208}$ are examples of provincial legislation that provide comprehensive specific bylaw passing powers, duties, and functions to municipalities for managing roads, including, for example, initial construction and maintenance, road signage, parking, and fencing. There are no similar federal or provincial laws providing specific bylaw passing powers for managing human activities in and around local water bodies, nor do any provincial laws specifically limit the special powers granted in s. $60 .{ }^{209}$

The Water Act, supra note 8, and the EPEA, supra note 22, do regulate some municipal activities that affect local water bodies. Some provincial legislation enables municipalities to become "agents" for the purpose of implementing provincial regulations within municipal boundaries. However, there are no provisions in any enactment that specifically address s. 60 powers. 
While the Water Act, the EPEA, and the Public Lands Act have comprehensive regulatory schemes, it might be possible for s. 60 bylaws to enhance the provincial regulatory schemes by addressing matters of a local nature, for example the regulation of removal of riparian vegetation, pesticide application for cosmetic purposes, and planting of invasive species. These activities on private lands may pollute local water bodies or destroy indigenous species in riparian lands.

In combination with natural person powers, municipalities may enact water body management bylaws to control and manage a broad scope of human activities that might impact water bodies and their beds and shores. Municipal water body management bylaws and associated water body management plans could be framed in accordance with the Water Act, the Framework for Water Management Planning, and the embedded "Strategy for the Protection of the Aquatic Environment."210

As stated above, provisions in the Water Act enable the Minister charged with implementation of the Water Act to enter into agreements with municipalities and other local authorities with respect to a number of matters including:

(a) any matter pertaining to the conservation and management of water, including but not limited to the supply and control of water,

(b) water-power development,

(c) the use, operation, maintenance, repair, control, replacement or removal of works,

(d) flood control and management,

(e) trans-boundary water, and

(f) any other matter related to the administration [of the Water Act]. ${ }^{211}$

The Province could encourage municipalities to exercise the special power granted in s. 60, and three starting points could be to address issues of water conservation, flood control, and storm water management. ${ }^{212}$ However, the scope of local environmental matters that a municipality could manage through a water body management plan and municipal water body management bylaw seems to be broad.

\section{E. SUMMARY}

Based on the legislative history of the phrase "direction, control and management” and the arguments presented above, I summarize as follows:

- $\quad$ The limitations on the special municipal power to manage water bodies are found in the section itself: s. 60 is "subject to any other enactment.” Therefore, a s. 60 bylaw must be consistent with any other federal or provincial law or regulation. terms and conditions, including but not limited to provisions for sharing of costs."

212 See the Alberta Water Council work to date on watershed management planning and shared governance wherein municipalities are established as important partners in watershed management planning and implementation of such watershed plans: see "Shared Governance \& Watershed Planning Framework Project Team Terms of Reference," online: AWC <http://www.albertawatercouncil.ca>. 
- $\quad$ Municipalities are authorized to direct, control, and manage all local natural water bodies whether the presence of water is intermittent or occurs only during a flood.

- $\quad$ As s. 60 does not stipulate how the authority granted is to be exercised, a council could enact bylaws or pass resolutions to achieve their objectives for direction, control, and management of local water bodies.

- $\quad$ The scope of local environmental matters that could be addressed through a water body management plan is broad.

- A s. 60 water body management plan could be implemented through a s. 60 bylaw; Part 17, s. 640 land use bylaw regulation; and a Part 2, s. 7 bylaw.

\section{CONCLUSION}

Alberta's wetlands have been identified as Genuine Progress Indicators of Alberta's "common wealth" and are important features of safe and viable communities. The Province has recognized that wetlands and associated riparian lands must be maintained, restored, and enhanced in the Framework and "Strategy for Protection of the Aquatic Environment." Wetlands cannot be managed in isolation from adjacent riparian lands or the aquatic environment of which they are a part.

Alberta municipalities could be using water body management plans and water body management bylaws to protect wetlands and associated riparian lands in the White Zone from the impacts of human activities and development.

As wetlands and associated riparian lands are elements of the "aquatic environment" that provide many economical, social, and ecological goods and services to society, and are indicators of society's “common wealth,” they need to be protected by municipal councils in the overall greater public interest. If municipalities do not take action to manage these important natural resources at a local level, wetlands and riparian lands will continue to be impacted by human activities and destroyed to allow for increased residential, commercial, and industrial development.

Recently, Water For Life initiatives put a spotlight on the deficiencies in the Province's legislative schemes to conserve and manage wetlands and riparian lands. The Interim Wetland Policy, the Land Use Policies, and the Guide were adopted by the Province in 1993, 1996, and 2004 respectively. The Guide was revised in 2007. The recently released New Alberta Wetland Policy and Recommendations for an Alberta Wetland Policy Implementation Plan, ${ }^{213}$ prepared by the AWC, will require that all wetlands in Alberta, whether in the White Zone or Green Zone be conserved in accordance with the policy and implementation plan. Recommendations for an Alberta Wetland Policy Implementation Plan (Edmonton: Alberta Water Council, 2008) wherein the AWC adopted the work of the project team above and forwarded AWC recommendations to Alberta Environment for adoption as provincial policy. Twenty-three of the 25 sectors represented in the AWC supported the recommendations to the Province, with only the Alberta Chamber of Resources and Canadian Association of Petroleum Producers having not agreed to the final submission. 
The New Alberta Wetland Policy and implementation plan demonstrate that the status quo of continued wetland loss is unacceptable. Stripping and grading, draining and filling of wetland complexes, and destruction of valuable riparian habitat necessary for many species of wildlife and waterfowl are not things of the past as these activities continue in spite of the Interim Wetland Policy. ${ }^{214}$

Ownership of the beds and shores of wetlands is problematic because municipalities cannot be sure who owns these lands until a surveyor determines the delineation of the legal bank during subdivision process. The Province complicated the ownership dilemma by stating that only the beds and shores of "permanent and naturally occurring” wetlands are claimable under s. 3 of the Public Lands Act. There is disagreement about what constitutes a permanent wetland, and, over time, the Province may decide that the beds and shores of ephemeral water bodies should be retained for the ecological benefits they provide to society.

Statutory authority for municipal management of local water bodies, as provided in s. 60, needs to be further translated into provincial policy to ensure that municipalities embrace their responsibilities for local "direction, control and management" of wetlands and associated riparian lands and aquifers. Even so, without any legislative change, municipal water body management bylaws may be enacted under s. 60 to address a broad scope of local matters related to local water body management to ensure that impacts on local water bodies and associated riparian lands are minimized. Limitations on municipal water management bylaws and plans are found in the Water Act, the EPEA, the Public Lands Act, the Fisheries Act, etc., but there are a whole range of local water body management issues that municipalities already address through bylaws and resolutions that are consistent with provincial and federal laws. Municipalities should pay close attention to the creation and implementation of regional plans created pursuant to new legislation in the Alberta Land Stewardship Act, which will provide municipalities with new regulatory tools and policy guidance for protecting wetlands, riparian lands, and other environmentally sensitive landscapes. $^{215}$

I conclude that, in the White Zone, Alberta municipalities could manage these features of the natural environment for the continued health and welfare of current and future generations of Albertans who live, work, and play in the White Zone. Doing so would be in the overall greater public interest. accommodate a car dealership. In the recent Westridge Area Structure Plan, the Town of Cochrane approved that the developer eliminate all but three wetlands in a 43 wetland complex. Two of those "saved" wetlands will be used as storm water treatment facilities. 